\title{
La obra de Juan Pascual de Mena y el singular conjunto escultórico de Torrecilla en Cameros (La Rioja)
}

\author{
The work of Juan Pascual de Mena and the singular \\ sculptural assembly of Torrecilla en Cameros (La Rioja)
}

Antonio J. DÍAZ FERNÁNDEZ

Doctor en Historia del Arte

Recibido: $21 / \mathrm{XII} / 2017$
Aceptado: $3 / \mathrm{V} / 2018$

RESUMEN: La iglesia parroquial de Torrecilla en Cameros (La Rioja) se enriquece principalmente con una imagen de la Inmaculada Concepción que forma parte, con otras cinco esculturas, del conjunto encargado en 1759 para el hoy desaparecido convento franciscano de su advocación. Aquí se analizan éstas y otras tres tallas más que muestran el estilo personal que el escultor académico Juan Pascual de Mena (1707-1784) imprimió a la escultura madrileña de su tiempo y cuyo arte se difundió ampliamente en otras zonas.

Palabras clave: Escultura española siglo XVIII; Inmaculada Concepción; Juan Pascual de Mena; Torrecilla en Cameros; La Rioja.

ABSTRACT: The parish church of Torrecilla en Cameros (La Rioja) is mainly enriched with an image of the Immaculate Conception, that forms part with five other sculptures, of the set commissioned in 1759 for the Franciscan convent of his invocation and now disappeared. Here are analyzed these and three other works that have the personal style that the academic sculptor Juan Pascual de Mena (1707-1784) gave to the Madrid's sculpture of his time, and whose art spread widely in other areas.

Keywords: 18th century Spanish sculpture; Immaculate Conception; Juan Pascual de Mena; Torrecilla en Cameros; La Rioja.

La iglesia parroquial de San Martín de Torrecilla en Cameros, en La Rioja, atesora dentro de sus muros un conjunto de esculturas del siglo XVIII de clara procedencia madrileña que la documentación corrobora puntualmente. Además, la ya conocida existencia de un grabado coetáneo revela la asignación de la obra principal al escultor madrileño de origen toledano Juan Pascual de Mena y su datación a partir de una fecha concreta, la de $1759^{1}$. Se explica la localiza-

1 J. G. MOYA VALGAÑÓN, "Sobre algunas ción de estas obras lejos del medio propiamente cortesano en que se desenvolvía el artista en razón de un hecho social frecuente en la época como es la fundación pía de un establecimiento religioso o el fomento de una devoción en el terruño de origen, actuación en la que el arte seguía teniendo una pri-

esculturas cortesanas dieciochescas", Cuadernos de Investigación Histórica Brocar, no 14, 1988, pp. 157-169; J. M. RAMÍREZ MARTÍNEZ, Torrecilla en Cameros: guía histórico-artística, Torrecilla en Cameros, 1993, p. 29 (en nota 22); L. PÉREZ DE DOMINGO, El escultor Juan Pascual de Mena en Madrid, Madrid, 2007, pp. 190-191. 
mordial misión instrumental a través de un patrocinio cualificado. Con ello nos remontamos a los primeros años de la segunda mitad del siglo XVIII a partir del compromiso de un natural de Torrecilla en Cameros con la orden de San Francisco. Fue la voluntad de don Juan Manuel Hermoso de Ordorica fundar una pequeña casa de religiosos franciscanos con título de la Inmaculada Concepción en su villa natal. Hijo de don Blas Hermoso de Ordorica y doña Ángela Martínez de Pinillos ${ }^{2}$, este prohombre residía en la Corte desempeñando el cargo de Secretario en el Consejo de Su Majestad a la vez que el de mayordomo de la Dignidad Arzobispal de Toledo en su partido eclesiástico de Madrid, y del que sabemos de su confirmación de privilegios de hidalguía en el año de 1751 en reconocimiento del expediente personal presentado en la Real Chancillería de Valladolid por su padre en $1744^{3}$.

2 Blas Hermoso de Ordorica nació en 1675 en Torrecilla en Cameros y era Alcalde de la Santa Hermandad en 1747, y de cuyo matrimonio con Ángela Martínez de Pinillos y Sáenz de Villarreal (Torrecilla en Cameros, 1680) nació Isabel, hermana de Juan Manuel, que en su matrimonio con Diego Marcos Sáenz procrearon a Blas Policarpo Sáenz de Tejada y Hermoso de Ordorica, Larios y Martínez de Pinillos, nacido en la villa en 1744, que fue Alcalde Mayor del solar de Tejada (1765), caballero de la Orden de Carlos III con pruebas de nobleza desde 1788, inscrito en el Cuerpo de Hijosdalgo de la Nobleza de Madrid, secretario de la Sociedad de Madrid y con Real Carta Ejecutoria de Nobleza en Valladolid. Véase M. ZABALA MENÉNDEZ, "Riojanos en el Real Cuerpo de la Nobleza de Madrid (17821909)", Boletín de la Asociación Riojana de Genealogía y Heráldica (A.R.G.H.), nº 6, 2014, pp. 49-72.

${ }^{3}$ Archivo Histórico Nacional (en adelante AHN), Archivo de la Real Chancillería de Valladolid, Real Audiencia y Chancillería de Valladolid, Registro de Vizcainías, Caja 8, 2. Es la "Real provisión de vizcainía expedida a petición de Juan Manuel Hermoso de Ordorica, secretario y mayordomo del Arzobispado de Toledo, vecino de dicha ciudad, natural y originario de Torrecilla en Cameros (La Rioja)". La condición de hijodalgo de don Juan Manuel Hermoso de Ordorica estaba acreditada por una ascendencia nobiliaria que se remontaba a Francisco Hermoso de Ordorica, dueño de la casa solar infanzona y torre de Ordorica, en la anteiglesia de Ugarte de Múgica, merindad de Busturia, señorío de Vizcaya. Un hijo de este antepasado, Miguel Hermoso de Ordorica, de oficio arquitecto, fue quien se afincó en

\section{LA FUNDACIÓN DEL CONVENTO FRANCISCANO}

Ya ha sido suficientemente documentado el proceso de fundación escriturado en Torrecilla en Cameros en 7 de septiembre de 1759 ante el escribano Juan Francisco Fernández de Ibarra, estando presentes de una parte los Muy RR. PP. Fr. Francisco Garraza, Lector Jubilado y Ministro Provincial, Fr. Bernardino Boleaga, Lector Jubilado y Custodio, y Fr. Manuel Collado, Definidor por la Santa Recolección (todos, observantes franciscanos de la Santa Provincia de Burgos), y, de otra, el señor don Juan Manuel Hermoso de Ordorica, cumpliendo así con la idea de fundar en su patria un "oratorio u ospizio con su yglesia avitaz ${ }^{\circ}$. y demas ofizinas correspondientes todo a sus expensas, proveyendo uno y otro asi de los vasos sagrados y ornamentos, como de todos los demas utensilios preziosos, à honrra y gloria de Dios, y de la Ynmaculada Conzepcion de nuestra Sa . la Virgen Maria, cuio ynefable Misterio ha de ser el titulo, ô adbocacion de dho oratorio..."4. A ello se sumarían las previsiones que don Juan Manuel dispuso luego en vida, pues su fallecimiento no sucede hasta el 3 de diciembre de 1772 en la villa de

Torrecilla con motivo de asistir a la obra de la iglesia de Pinillos, donde contrajo matrimonio en 1596, habiendo muerto en un accidente en dicha obra.

${ }^{4}$ Archivo Parroquial de Torrecilla en Cameros (en adelante APTC), Libro [1ํ "... que contiene la fundacion del Convt ${ }^{\circ}$. de la Purissima Concepn. en esta villa de Torrezilla de los Cameros...", fol. 3v (ejemplar copia para el cabildo de curas). D. Juan Manuel comparecía en nombre propio y también como apoderado del M. R. P. Fr. José Alonso de Pinedo, de la orden de predicadores del convento de Santo Tomás de la villa de Madrid (este como testamentario a su vez de don Pedro Cristóbal Hermoso, su hermano difunto, y en razón de una escritura anterior en favor del convento de Jesús de la villa de Navarrete de 14 de abril de 1753, que quedaba revocada en ese mismo acto) por el poder otorgado en 27 de julio de 1759 ante Bernardo Ruiz del Burgo, escribano del rey y número de la villa de Madrid; y actuaba impulsando una idea propia posterior a la intención frustrada de su hermano que habría de materializarse en la fundación torrecillana. 
Madrid ${ }^{5}$, en donde extiende su testamento, favoreciendo la ampliación del patronato de sangre, y cuyo mandato sería diligenciado por su viuda $D^{\mathbf{a}}$ Josefa Manzano y Coronel y demás testamentarios en 30 de julio de 1773 ante el escribano José Pérez del Aya ${ }^{6}$.

El que era Secretario del rey contaba desde su primer momento con una más que previsible autorización de Fernando VI. Así, una Real Provisión resolvía la petición del fundador presentada ya en 15 de abril de 1755, otorgando licencia en Madrid en 23 de septiembre de 1757, finalmente refrendada por la certificación de don Ramón de Barajas y Cámara, Secretario de Cámara del Rey, en Madrid en 26 de mayo de 1759, a la vista de la excepcional Bula Apostólica de Benedicto XIV (dada en Roma, en Santa María la Mayor bajo del Anillo del Pescador, en 2 de mayo de 1758) presentada oportunamente a los efectos y de la que se infiere el compromiso de "que la yglesia que alli se ha de edificar y dedicar a Dios nro sôr. en honor de la Conzepcion ynmaculada de la vienaventurada virgen Maria, ha de tener, tres Altares, o Capillas, su sagrario, puerta, y entrada publica, campana, y campanilla y en esta misma Yg ${ }^{a}$. ha de estar custodiado continuamte. el santisimo Sacramento de la eucharistia la

${ }^{5}$ J. M. RAMÍREZ MARTÍNEZ, Op. cit., pp. 39-44. De hecho, en Madrid en 2 de agosto de 1770, ante el escribano de la villa Manuel Gómez Guerrero, el patrón otorgaba escritura de un censo de 88.500 reales de vellón a favor del convento franciscano de su fundación (APTC, Libro [1ํํㄱ, fol. 101 y ss.).

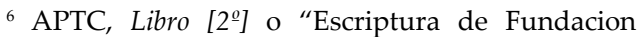
de un Patronato que erigio el Sr. Dn, Juan Manuel Hermoso y agregó à el del Comvt ${ }^{\circ}$. de la Concepciô. de la Villa de Torrecilla de los Cameros...", fol. 1 y ss. (copia para la iglesia parroquial). Además de la viuda, eran sus testamentarios D. Pedro Manzano y Coronel, presbítero capellán de honor de S. M., D. José Alonso Pinedo, conventual de Santo Domingo en Santo Tomás, D. José Fernández Alejo, guardián del convento de San Francisco, D. Tadeo de Liébana, religioso lego del mismo convento y postulador de la causa de la Venerable Madre María de Jesús de Ágreda, D. Manuel Navajas Hermoso, D. Policarpo Sáenz de Tejada Hermoso, D. Pedro Escolano y Arrieta, escribano de Cámara del Real Consejo de Castilla, y D. Andrés Ángel Payán, todos avecindados en la Corte. qual yglesia, promete el suplicante adornar, con sagrario, basos sagrados, ornamentos dezentes comformes a los colores de q-. usa la Yga Romana..."7.

Y no menos explícitos, por necesarios, el convenio y acuerdos de 22 de septiembre de 1758 sobre competencias entre la Provincia de Burgos de N. P. S. Francisco y el Cabildo de curas y beneficiados de la villa de Torrecilla en cuanto al régimen de gobierno y constituciones del pretendido oratorio. Edificado en un suelo comprado en 1757 en el paraje llamado "el Prado", la escritura fundacional delimita y describe los inmuebles cedidos a la incipiente comunidad ${ }^{8}$. Particularmente interesante es la alusión concerniente al interior de la capilla, que se describe como una nave de 76 pies de largo y 23 de ancho y 35 de alto $(21,28,6,44$ y 9,80 metros respectivamente), en donde se sitúan los tres retablos principales que se hacen bajo su ordenamiento sobre todo respecto a las devociones que habría de incluir, tratándose de imágenes de talla todas ellas, y alguna con su dotación de fiesta y misas. Así pues, se señala, con la misma evidencia de estar ya todo realizado y visible, en el nicho preferente del retablo mayor la Inmaculada Concepción, flanqueada

${ }^{7}$ APTC, Libro $\left[1^{o}\right]$, fol. 12 y ss.

${ }^{8}$ Ibídem, fol. 29 y ss. El fundador se había adelantado con la construcción de un pequeño hospicio y oratorio con el título de la Purísima Concepción para habitáculo inicial de cuatro frailes franciscanos, haciendo exacta medida de la fachada total a la plazuela, del oratorio con sus dependencias y cuya fábrica era de mampostería de cal y canto pero reforzadas las esquinas, y de sillería, faja y taludes; con las dos puertas principales de la iglesia y portería guarnecidas en piedra labrada, y sobre la primera el escudo de armas del fundador y encima las de la orden religiosa, y sobre la otra un escudo franciscano; todas las ventanas con marcos de toba; cerrando el frontis de la iglesia una espadaña de piedra y habiéndose previsto la introducción en un hueco de los cimientos de una caja en la que se escribió la siguiente memoria: "Anno millesimo septingentesesimo quinquagesia octaba Dominico Sagre Aedis imperium habente domino Santissimo quidem Patre nostro Benedicto Dezimo quarto, felicies recordatione in decimo nono cuius pontificatun...". Documento transcrito en J. M. RAMÍREZ MARTÍNEZ, Op.cit., p. 94. 
en los laterales por las de sus padres San Joaquín y Santa Ana; y en la parte superior del retablo un San Francisco de Asís superado por un Espíritu Santo acompañado de dos serafines en el coronamiento. A continuación se constatan brevemente los dos colaterales en nichos bien guarnecidos, dedicado el primero a San Juan Bautista y el segundo a San Antonio de Padua, cuyas imágenes no parece se acompañen de otras menores o secundarias, pero sí de sendos medallones de pintura en los áticos de los respectivos retablos representando a San José y a San Pedro ${ }^{9}$.

\section{EL CONJUNTO ESCULTÓRICO}

En la documentación fundacional no hay mención a ninguna otra imagen o devoción, por lo que en el pequeño templo franciscano se llegaron a colocar seis esculturas principales que el fundador tuvo que encargar en Madrid a uno de los escultores que descollaban entonces en el ámbito cortesano y que mejor podía representar el fin altruista encomendado a la devoción personal, a la vez que reafirmaría ante sus paisanos y con suficiente brillantez el prestigio y solidez de la donación. El promotor, directa o indirectamente, dejaba así en manos del escultor y académico Juan Pascual de Mena esta importante misión, pues es este artista el que sin duda labró no sólo la emblemática Inmaculada Concepción, sino también el resto de las tallas, como será oportuno fundamentar, si bien se pensaba que eran solamente dos las obras seguras de Pascual de Mena reducidas a la titular y al San Juan Bautista. La primera de ellas por su probada identificación con la estampa dedicada en 1759. Es cierto que ya José M. Ramírez Martínez se convenció de la pertenencia de las demás al escultor y su círculo y definitivamente Lorenzo Pérez de Domingo recogió en su tesis estas imágenes dentro del catálogo de obras realizadas

9 La iglesia se conserva hoy, después de su desamortización y habiendo pasado por distintos usos, definitivamente transformada en gran salón expositivo del Centro de Interpretación de la Emigración Riojana, inaugurado en octubre de 2008. por el escultor madrileño para otras provin$\operatorname{cias}^{10}$.

Pero antes de considerar cada una de estas imágenes e individualizarlas fuera de su contexto primigenio, tal y como hoy se hallan repartidas en la parroquia de San Martín de Torrecilla en Cameros, pretendemos lo contrario, vincularlas como un todo dentro de lo que fuera el encargo original y contextualizar el conjunto con destino conventual, pues también es cierto que otras imágenes ya de exclusiva propiedad parroquial se sumarán a esta relación de imágenes madrileñas y serán consideradas de igual modo. Así pues ¿cuándo situar la realización de los tres retablos de la iglesia franciscana de Torrecilla en Cameros y sus correspondientes imágenes?

Es evidente que una fecha sirve de referencia irrefutable y es la dada, como queda dicho, por la publicación de la celebrada estampa de la Inmaculada Concepción en su convento de San Francisco de Torrecilla en Cameros, grabada por Juan Bernabé Palomino en el año de 1759, a cuyo pie se recoge con profusión de abreviaturas: "Is Pal Mena invt et in Lignm sculpt; Is Palom ${ }^{\circ}$ sculpr Regs Matti incidt", y expresando la leyenda que la imagen de que se trata es el "Verdo Retto de la Portentosa Imagen de María Ssma de la Concepción. Patrona de Espña y de las Inds según se vena en el Convto... de la $\mathrm{V}^{\mathrm{a}}$ de Torrezilla d los Cameros Prov ${ }^{\underline{a}} \mathrm{~d}$ Burgos"11 $^{\prime \prime}$ (Fig. 1). Es decir, encabezado por la de Nuestra Señora, el conjunto de las seis imágenes sería esculpido por Juan Pascual de Mena (Villaseca de la Sagra, 1707-Madrid, 1784) dentro de la que es sin duda su etapa más fecunda, la de su ecuador profesional y en plenitud de su carrera, en torno a los cincuenta años de edad, siendo un escultor muy reputado en el medio madrileño y académico. $\mathrm{Y}$ en su correlación con el resto de obra del

${ }^{10}$ J. G. MOYA VALGAÑ́́N, Op.cit., pp. 157-169. J. M. RAMÍREZ MARTÍNEZ, Op.cit., pp. 29-36 y L. PÉREZ DE DOMINGO, Op.cit., pp. 217-220.

11 Biblioteca Nacional, INVENT/13062. E. PÁEZ RÍOS, Repertorio de grabados españoles en la Biblioteca Nacional, Madrid, 1981-1985, T. II, p. 344, no 1591/68. 


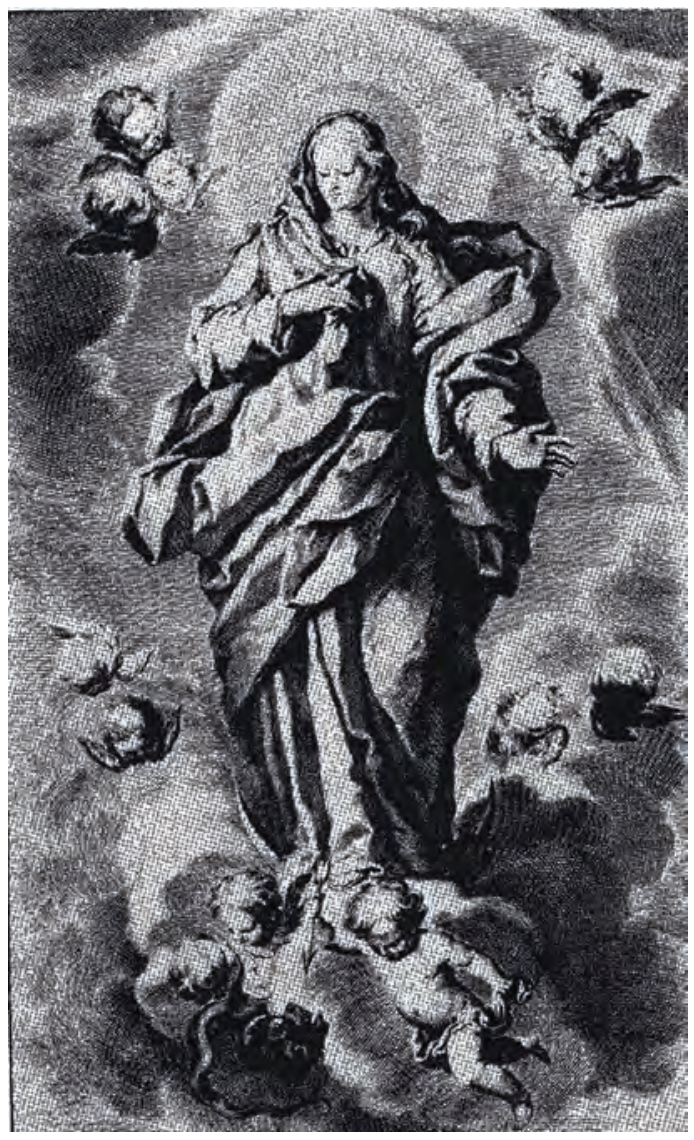

- Fig. 1. Juan B. Palomino. Grabado de la Inmaculada Concepción de Torrecilla en Cameros, La Rioja. 1759. Tomado de J. G. Moya Valgañón.

artista se sitúa con posterioridad a la magna obra labrada para la iglesia parroquial de San Nicolás de Bari de la villa de Bilbao (1754-56) y al señero conjunto del templo de San Marcos de Madrid (1757), precediendo en muy pocos años a las imágenes y diferentes elementos escultóricos del retablo mayor de la iglesia madrileña de las mercedarias descalzas, vulgo las Góngoras, (1762-63) y al posterior trabajo realizado para el trascoro de San Millán de la Cogolla de Yuso (1766), por mencionar únicamente lo mejor de la producción del escultor en tanto que conjuntos afortunadamente conservados ${ }^{12}$. Aunque

12 J. J. MARTÍN GONZÁLEZ, Escultura barroca en España (1600-1770), Madrid, 1983, pp. 375-407. Estudios concretos de J. NICOLAU CASTRO, "El escultor Juan Pascual de Mena", Goya: Revista de arte, no 214, 1990, pp. 194-204; L. PÉREZ DE DOMINGO, Op.cit., pp. 158161; J. Á. SÁNCHEZ RIVERA, "El retablo mayor de la iglesia del convento de mercedarias de la Purísima es obvio que existieron encargos de esculturas aisladas realizadas en esos diez años cruciales de 1755 a 1765 en que de Teniente Director asciende al cargo de Director de Escultura dentro del escalafón académico de la de San Fernando, habiendo terminado de esculpir en piedra para el palacio real nuevo de Madrid varias figuras de reyes, así como para el salón de juntas de la institución académica el siempre alabado busto en mármol de Carlos III, firmado y fechado en 1764. Año al que corresponde precisamente el hermoso San Eloy en gloria conservado en la iglesia parroquial de San José de Madrid ${ }^{13}$.

Aunque ya desde 1746, Pascual de Mena, con treinta y nueve años de edad, había madurado un estilo propio patente en imágenes religiosas tan personales y memorables como las desaparecidas de San Fermín de los Navarros de Madrid -la de Ntra. Sra. del Patrocinio y la de San Juan Bautista predicando- y a cuyo momento corresponde asimismo la no menos delicada talla de Ntra. Sra. de las Mercedes (1747) de su villa natal, hasta ahora la más temprana de las documentadas y felizmente conservada ${ }^{14}$.

Concepción en Madrid", Cuadernos de Arte e Iconografía, no 25, 2004, pp. 197-214 y M. T. RUIZ BARRERA, “Una obra documentada de Diego Martínez de Arce y Juan Pascual de Mena en el convento madrileño de las Góngoras", Estudios: revista trimestral publicada por los Frailes de la Orden de la Merced, no 237, 2008, pp. 103-112; J. M. RAMÍREZ MARTÍNEZ, "Juan Pascual de Mena en San Millán de la Cogolla", Kalakorikos, no 2, 1997, pp. 301-308.

${ }^{13} \mathrm{La}$ imagen fue labrada para el retablo mayor de la parroquia de El Salvador de la villa de Madrid por encargo del Gremio de Plateros madrileños.

${ }^{14}$ J. NICOLAU CASTRO, Op.cit., pp. 195-197. En esta serie de vírgenes sedentes, Nicolau relaciona con la Virgen del Patrocinio la del Rosario de la parroquia de Rascafría, procedente de una de las capillas de la cartuja de El Paular de Madrid, que bien puede datarse antes de 1750, mientras que la también muy similar de Ntra. Sra. de la Consolación y Correa de los agustinos de San Felipe el Real, hoy en la parroquia madrileña de Ntra. Sra. de la Esperanza, puede ser de hacia 1766. Sobre la biografía del escultor, A. J. DÍAZ FERNÁNDEZ, “Notas para la biografía del escultor Juan Pascual de Mena", Boletín del Seminario de Arte y Arqueología, nº 52, 1986, pp. 501-508. 
Desconocemos si, en el caso de Torrecilla en Cameros, el trabajo con el escultor lo convino el propio comitente, pero lo cierto es que en Madrid hubo de cerrarse este contrato de empeño quizás a partir de 1758 para su ejecución en el plazo de un año, a la par que se estaba construyendo la capilla de destino. De hecho, la piedra angular de aquel primer conventillo franciscano se colocó en 10 de abril de 1758 por el maestro de obras vecino de Corella José de Abós y la entrega del inmueble a los religiosos se hizo, como queda patente en 7 de septiembre de 1759, con la referida formalización de la fundación del hospicio y oratorio franciscanos bajo el título de la Purísima Concepción, con la consiguiente creación de un patronato el 5 de diciembre de ese mismo año, dada en Torrecilla en Cameros ante el escribano Fernández de Ybarra, mientras que la elevación a verdadero convento adscrito a la Provincia de Burgos se confirmó en 16 de enero de 1764, con el acuse de recibo de adornos, ornamentos y demás alhajas por Fr. Buenaventura Arnedo, presidente de dicho convento, de 7 de mayo de 1767, después de efectuadas las obras de ampliación del espacio claustral ${ }^{15}$.

Y es más que probable que también en Madrid se le solicitara las trazas al arquitecto igualmente señalado que actuara en pos de un proyecto total convenido entre el propio tracista y el escultor, en una de esas frecuentes asociaciones entre artistas y con el pleno asentimiento y supervisión del promotor ${ }^{16}$.

${ }^{15}$ APTC, Libro [2ํㅜ, fol. 1r-2v. J. M. RAMÍREZ MARTÍNEZ, Torrecilla en Cameros..., pp. 41-42.

${ }^{16} \mathrm{El}$ documento fundacional describe textualmente: "Retablo maior y Santos. Un retablo maior de madera de pino dorado que se compone de su pedestral, sagrario, tavernaculo para exponer á nro $\mathrm{s}^{\mathrm{o}} \mathrm{r}$. Sacramentado, arco de medio punto y trasparente y en el colocada una ymagen de la purisima Conzepcion con su trono de serafines, y en la caveza una laureola de doze estrellas dorada, y sobre este [arco] un glovo de nubes, y en el la ymagen de nro Padre Sn. Franc ${ }^{\circ}$. de Alferez, con su vandera, diadema, cordon, y rosario de Nacar, coronando dho retablo maior, un espiritu santo adornado de rafagas y dos serafines en los dos angulos ò extremos.- Dho retablo maior se halla guarnecido con quatro columnas axtreadas, dos â cada costado, y en el
Pero no tenemos datos del autor o constructor de los tres retablos, que hemos de dar por desaparecidos, ya que no existen elementos en la iglesia parroquial con los que se puedan relacionar, teniendo por destruidas o perdidas también las esculturas de los dos ángeles que junto al Espíritu Santo coronaban el principal. Pérdidas debidas a la exclaustración de 1836, con el consecuente cierre del convento y el paso de su patrimonio y objetos de culto a posesión del cura párroco de la villa, aunque parece que a instancias del

intercolumnio al pie, se hallan colocadas las ymagenes de San Juaquin y St ${ }^{\mathrm{a}}$. Ana con sus diademas, y el trono de nrâ $S^{a}$. se halla adornado con su cortina exterior de tapizeria blanca forrada en tafetan carmesi, y otra ynterior al trasparente de tafetan doble carmesi, y dos arañas doradas de a tres mecheros cada una, colgadas con sus cadenetas de yerro y cordones de seda carmesi, delante de nrâ $S^{a}$. y sus borlas de seda del mismo color.A los dos estremos de dho retablo maior se hallan colocadas dos puertas uniformes que se comunican a la sacristia con sus varillas de yerro y cortina de tafetan doble nubado con sus sortijas doradas y su yladillo al canto de ellas y sobre cada una de dhas puertas, un escudo de armas del fundador de madera, con su relieve y talla correspondiente todo dorado; su mesa de altar, con su ara correspondiente y marco dorado, para recivir los frontales y su campanilla de metal fixada con su cadenita de yerro y dha mesa es en la figura regular para contener frontales.- El sagrario contiene su barilla dorada con su cortina de tisu, y sus sortijas correspondtes.; una soga colgada en el punto medio de dha capilla maior, con su cadena para colgar en ella la lampara. Colaterales y Santos. Dos retablos colaterales de la misma madera dorados, sentados en dos huecos de pared proporcionados para ellos, que se componen de su pedestral, sagrario, y grada, con un nicho entre sus dos columnas astreadas, y en el uno colocada la ymagen de San Juan Bauptista con el cordero y vara, tallado de pieles con su diadema y desnudo; y en el otro la ymagen de Sn. Antonio de Padua, tambien con su diadema, cordon y rosario de nacar, con el niño Dios en los brazos, y en una mano un ramo de flores, con la Azuzena, y por remate un zirculo âobado adornado de su talla, que contiene una pintura de San Joseph encima del San Juan. y una de Sn. Pedro encima del Sn. Antonio con los àdornos de sus estremos, cada colateral tiene su mesa de altar, arrepisada como se estila, sin marco ni frontal, pintada, con cuio adorno sirve a pres-. y tambien su tarima al pie, y su campanilla fixada con su cadenita en dha mesa de altar, y su sagrario con su barilla y cortina de tela..." (APTC, Libro [1ํ], fol. 32v-34). Transcrito en J. M. RAMÍREZ MARTÍNEZ, Torrecilla en Cameros..., pp. 103-104. 
todavía existente patronato se intentaron recuperar en algún momento sus bienes. Pero, tras la definitiva desacralización del templo, la destinataria de la riqueza artística fue la parroquia de San Martín, en donde quedó depositado a mediados de 1867 el total de imágenes, ya sin los retablos originales, acomodándose algunas de ellas en retablos preexistentes y otras sin una ubicación concreta o incluso siendo arrinconadas fuera de culto ante la renuncia total y donación de su entonces patrono don Gregorio Cruzada Villaamil ${ }^{17}$.

\section{ANÁLISIS ARTÍSTICO DE LAS IMÁ- GENES}

Es la iglesia de San Martín un templo de finales del gótico, de planta de salón, dividido en nueve ámbitos en el que se distingue un mobiliario de distintas épocas y estilos. El retablo mayor, de gran envergadura, es renacentista, usando de las columnas abalaustradas. Los dos colaterales son dispares, salomónico el del Evangelio y plateresco el de la Epístola, más otros dos retablos laterales que también responden al siglo XVII en sus dos etapas, la prechurrigueresca y la salomónica; $\mathrm{y}$, por último, dos retablos menores adaptados a los dos primeros pilares centrales, parejos y ya realizados en torno a 1760 en estilo rococó ${ }^{18}$. En esta iglesia parroquial se constata la existencia de varias esculturas de gran calidad, que son principalmente la Inmaculada Concepción, en su retablo de la nave del

\footnotetext{
17 Ibídem, pp. 43-44. Por cierto, los tres retablos vacíos serían puestos a disposición del cura párroco de Torrecilla en 1881 por don Gregorio Cruzada de Villaamil en carta dirigida desde Madrid (APTC, Libro $\left[2^{\underline{o}}\right]$, carta suelta). Los dos tondos que culminaban los retablos colaterales, con la representación de $S$. José y $S$. Pedro serían arrancados de sus áticos y hoy se conservan en el museo parroquial de arte sacro creado en 2005 por el entonces párroco D. Ángel F. Domínguez Tabernero.

${ }^{18} \mathrm{Mi}$ agradecimiento a D. Alejandro Pérez González, párroco de las iglesias de Torrecilla en Cameros, Nestares, Almarza y Pinillos, por franquearme en 18 de octubre de 2014 el archivo parroquial y permitirme el examen de las imágenes y la toma de fotografías aprovechadas en este trabajo.
}

Evangelio, San Joaquín y Santa Ana, situadas en hornacinas del basamento del retablo mayor, San Juan Bautista, sin altar propio en un colateral, y San Antonio de Padua, en el retablo del lado de la Epístola. Las cuales se corresponden sin error con la serie de esculturas procedente del extinguido convento franciscano. Como queda dicho, Ramírez Martínez reconoce la unidad del conjunto e incluye en el mismo las distintas imágenes conservadas en la parroquia y que aparecen relacionadas en la documentación de la fundación, pero sin detenerse en un análisis individualizado de cada una de ellas.

No obstante, también se descubren en la iglesia parroquial la Virgen del Rosario en su retablo de uno de los postes centrales y el majestuoso San Martín Obispo sedente que preside el retablo mayor. De igual modo, en el museo parroquial destacan un San Francisco de Asís y un San Nicolás de Bari, que son piezas de sumo interés, máxime cuando la figura del primero es la que se localizaba en el retablo mayor del antiguo convento, como así lo confirma la cartela que lo explica.

En cualquier caso, todas estas esculturas reunidas al presente en la iglesia parroquial de San Martín forman una colección de indudable carácter cortesano y debidas en concreto a las gubias del escultor e imaginero Juan Pascual de Mena, en una afirmación que lejos de ser infundada responde al riguroso análisis formal de cada una de ellas, rechazando el simple asomo de duda o de atribución titubeante. Un conjunto que, por otra parte, acusa notable deterioro en todas y cada una de las imágenes con daños evidentes en soportes y policromía, reclamando una restauración concienzuda que daría esplendor a todas las efigies. Esta ampliación del catálogo de la obra de Juan Pascual de Mena parte de la principal imagen, la Inmaculada, la primera en serle reconocida; y ha de seguirse con las otras cinco vinculadas a la fundación franciscana de 1759.

Comenzamos su estudio siguiendo un orden lógico en cuanto a la jerarquía icono- 
gráfica que tuvieron dentro del recinto conventual.

1.- Inmaculada Concepción (Fig. 2). Fue la advocación principal del suprimido convento, afirmada por la devoción particular del fundador, pero fomentada la cuestión doctrinal del misterio mariano por la misma orden franciscana antes de que el Papa Alejandro VII dictara en 1659 su Breve sobre el Misterio de la Concepción y antes de su definitiva presentación como dogma en 1854 . Cotejada la talla existente con el dibujo de la estampa conmemorativa, la imagen actual ha perdido las cabecitas y el querubín del trono, manteniendo el asiento de nubes aunque cortado en un plano horizontal para hacer base plana y perdiéndose así la gran masa y el efecto monumental que adquiriría la imagen dentro de su hornacina original situada ante el presumible transparente del retablo mayor conventual, ocupando un lugar preeminente y lumínico que justifica la posición de mirada hacia abajo de la imagen.

Ciertamente, imágenes de esta advocación en la producción de Pascual de Mena son pocas las conocidas hasta la fecha. No obstante, es oportuno advertir su cercanía con la Inmaculada de la iglesia navarra de Falces, datada en 1770 y no atribuida definitivamente -aunque se hace más que probable su autoría-, y muy lejos de la influencia de Luis Salvador Carmona, ya fallecido en $1767^{19}$, cuando Ramírez Martínez ya evidenciaba la conexión entre ambas tallas ${ }^{20}$. Respecto a ello, Pérez de Domingo también

19 R. FERNÁNDEZ GRACIA, La Inmaculada Concepción en Navarra: Arte y devoción durante los siglos del Barroco. Mentores, artistas e iconografía, Pamplona, 2004, p. 260. García Gaínza atribuyó en un primer momento las tres figuras del retablo a José Salvador Carmona así como las del retablo de la Virgen del Rosario, añadiendo el dato de la bendición en 1770 de la Inmaculada, traída de Madrid a expensas de D. Vicente Badarán, siendo los retablos datables en 1761-63, véase Ma . C. GARCÍA GAÍNZA, "Nuevas obras de Luis Salvador Carmona", Goya: Revista de Arte, no 221, 1991, pp. 277-283.

20 J. M. RAMÍREZ MARTÍNEZ, "Luis Salvador Carmona en Lumbreras de Cameros y Calahorra", Kalakorikos, no 2, 1997, pp. 97-113.

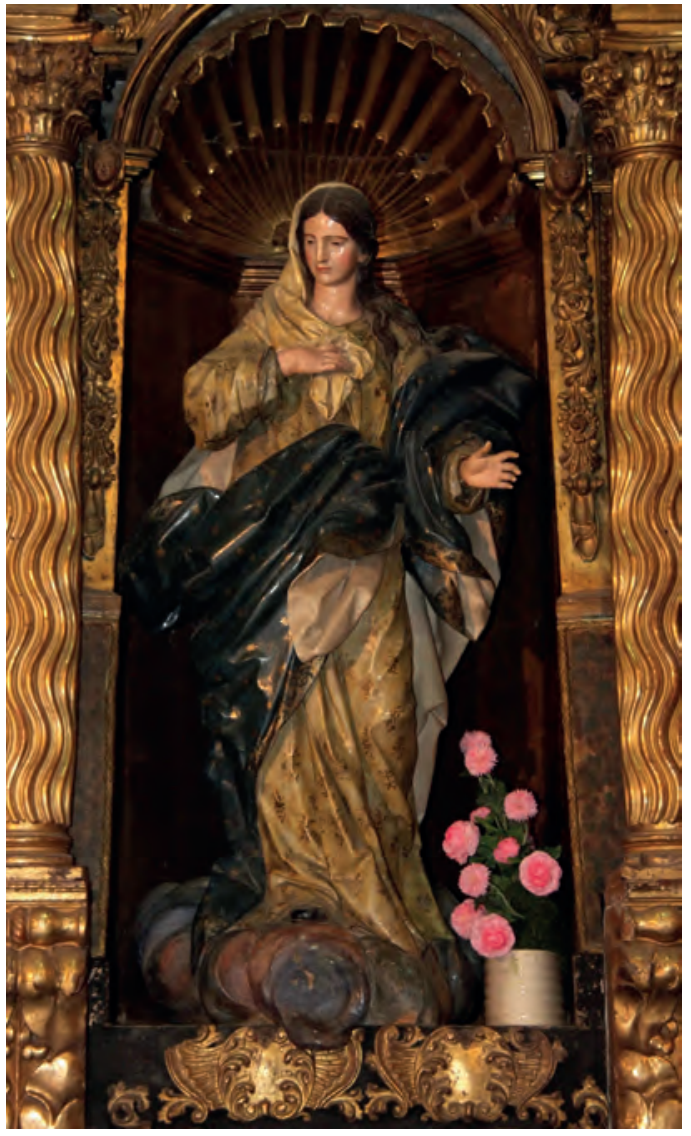

- Fig. 2. Juan Pascual de Mena. Imagen de la Inmaculada Concepción. 1759. Iglesia parroquial de S. Martín, Torrecilla en Cameros. Foto del autor.

la relaciona con la de Torrecilla y apunta la presumible autoría ${ }^{21}$, a la vez que atribuye acertadamente a Pascual de Mena la Inmaculada Concepción del convento de clarisas de Arizcun (Navarra), de evidentes similitudes compositivas y estilísticas con la de Torrecil$l^{22}$. Más aún sorprenden las analogías for-

${ }^{21}$ L. PÉREZ DE DOMINGO, Op.cit., pp. 222-223. También el profesor Urrea la relaciona con Juan Pascual de Mena, véase J. URREA, “La obra del escultor Luis Salvador Carmona en el País Vasco, Navarra y Castilla León", en Actas del IV coloquio nacional sobre la cultura en Andalucía. El escultor Luis Salvador Carmona (1708-1767). Conmemoración del III Centenario de su nacimiento (18 y 19 de septiembre de 2008), Serie Cuadernos de Estepa Edición digital, nº 2, Estepa, 2013, pp. 57-70.

22 L. PÉREZ DE DOMINGO, Op.cit., p. 228. Se sitúa en retablo propio al lado de la Epístola. Relación comparativa a la que debemos sumar oportunamente la imagen de la Inmaculada del coro alto de las clarisas de Guernica (Vizcaya), hasta ahora inédita, y que aquí no 
males con la Inmaculada, todavía anónima, de la sala capitular de la iglesia de la Concepción Real o de las Calatravas de Madrid, menos expresiva, pero tan similar que se diría una réplica exacta de esta de Torrecilla $\mathrm{y}$ que nos atrevemos a vincular al escultor aquí estudiado aun conociendo la atribución con reservas de Fernando Tabar Anitua a Salvador Carmona, que observa una forma más lisa y sintética de los plegados y por ello data la imagen con posterioridad a $1760^{23}$.

La delicadeza femenina y la belleza juvenil, junto a una sutil idealización, son primordiales en la representación de esta iconografía en la Inmaculada de Torrecilla. La cabeza asume el modelo definido por el escultor para María. De cuello largo y estilizado, la cara describe un óvalo de rasgos serenos y enmarcado de un lado por el velo, que se dispone por encima del pelo hacia atrás, cayendo por delante sobre el pecho donde es tocado con la mano derecha. Un tratamiento que muestra los parecidos entre la cabeza de esta efigie y la de Ntra. Sra. de la Correa (1766), semejanza todavía más visible en las fotos antiguas anteriores a su ubicación actual en la moderna parroquia de la Esperanza de Madrid. El mismo peinado del pelo ordenado en el medio, abierto sobre la frente y cayendo a los lados, a veces semioculto bajo el velo y, como en la de Torrecilla, derramado a lo largo del hombro izquierdo (Fig. 3). La figura se adorna con un ampuloso manto de caídas y vuelos jugando con mostrar por contraste el revés liso de las telas y reforzando el perfil ahusado y su contraposto marcadamente clásico. La policromía tiende a las telas naturales de colores planos, azul del manto y blanco roto de la túnica, pero

dudamos en atribuir a nuestro escultor e incluir en un próximo estudio.

23 F. TABAR ANITUA, "En las Calatravas de Madrid: Un maestro, Villabrille, un discípulo, Salvador Carmona y un rival, Pascual de Mena", en Actas del IV coloquio nacional sobre la cultura en Andalucía. El escultor Luis Salvador Carmona (1708-1767). Conmemoración del III Centenario de su nacimiento (18 y 19 de septiembre de 2008), Serie Cuadernos de Estepa - Edición digital, nº 2, Estepa, 2013, pp. 167-178.

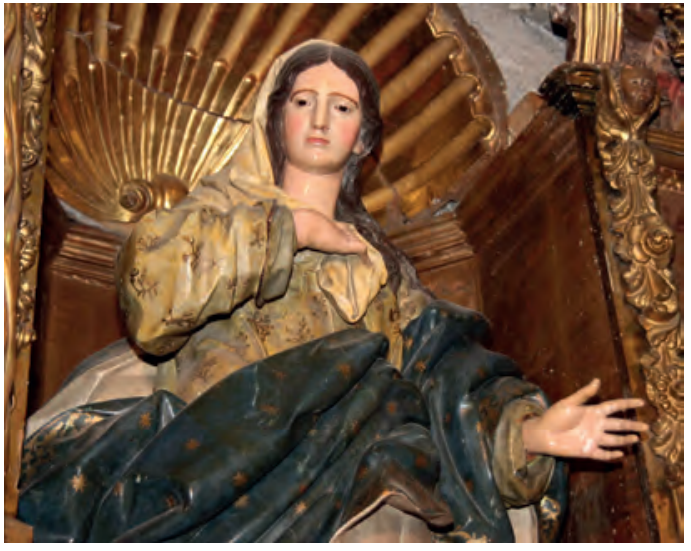

- Fig. 3. Juan Pascual de Mena. Imagen de la Inmaculada Concepción. 1759. Detalle. Foto del autor.

admite discretos dibujos dorados, como las orlas, el campo estrellado del manto y los ramitos señalados sobre la túnica. Pérez de Domingo da noticia de haber sido dada a conocer esta imagen riojana por Carlos Moya Valgañón y la ve llena de elegancia y de estilo claramente rococó, pero con atisbos de clasicismo en la búsqueda de la belleza formal y de las proporciones, comparándola asimismo con la mencionada Virgen de la Correa en cuanto al rostro y forma de echar el velo hacia atrás. También ve relación con la Dolorosa de la sacristía de la iglesia de Santa Cruz de Madrid, que se le quiere atribuir al escultor en cuanto a la gesticulación de sus manos y pliegues de las mangas ${ }^{24}$. A su vez, Juan Nicolau Castro observa una esbeltez acentuada por la disposición y caída de la túnica y una cierta artificiosidad en el vuelo del manto que contribuyen a dar una elegancia rococó a la imagen ${ }^{25}$.

Es así que la Inmaculada de Torrecilla responde en su tipo a un modelo que Juan Pascual de Mena hace suyo derivado sin duda de las hermosas figuras pictóricas de la escuela madrileña del barroco creadas por el pintor asturiano Carreño de Miranda y todavía presentes a principios del siglo XVIII a través de sus discípulos. Aunque ejemplos escultóricos en el siglo XVII no faltan,

${ }^{24}$ L. PÉREZ DE DOMINGO, Op.cit., pp. 190-191.

${ }^{25}$ J. NICOLAU CASTRO, Op.cit., p. 200. 
caso de la imagen para las MM. Agustinas recoletas de Pamplona de Manuel Pereira, es sobre todo en la primera mitad del siglo XVIII y desde Madrid que el tipo es adoptado incluso en la imagen de la Asunción de la iglesia de Adanero (Ávila), realizada en 1712 por el escultor José Galván (†1731), discípulo de Alonso Villabrille y Ron $^{26}$, o en la Inmaculada que otro asturiano afincado en Madrid, el escultor Juan de Villanueva Barbales (16811765), realizó para el retablo del evangelio de la catedral de Oviedo en torno a 1740 y como la anónima Inmaculada de la parroquial de Güeñes (Vizcaya) estudiada por Nicolau Castro $^{27}$. Pero también los académicos de la de San Fernando, como Salvador Carmona en su Inmaculada para Lesaca, lo mismo que Roberto Michel (1720-1786), en su imagen de 1785 para la capilla Palafox de la catedral de Burgo de Osma, y el valenciano José Puchol (1743-1797), discípulo de Pascual de Mena, en su Inmaculada de la catedral de Orihuela, se afirman en el modelo al que, por cierto, también responde la Inmaculada de la catedral de Calahorra, obra anónima madrileña de hacia $1752^{28}$. Y destaca su pose con una mano derecha sobre el pecho y la otra extendida, diferenciándose de otros escultores dieciochescos de una segunda generación que, con Isidro Carnicero (1736-1804) al frente, optan por modelos del barroco italiano (los de Parodi y de Ponzanelli) en los que el gesto de recogimiento se hace más patente al posar ambas manos sobre el pecho o al juntarlas en actitud orante ${ }^{29}$, como también

${ }^{26}$ F. COLLAR DE CÁCERES, "El sepulcro del obispo Idiáquez y sus autores: José Galván y Carlos de la Colina", Boletín del Seminario de Arte y Arqueología, no 49, 1983, pp. 503-508.

${ }^{27} \mathrm{~J}$. NICOLAU CASTRO, "Esculturas del siglo XVIII en la parroquia de Güeñes (Vizcaya)", Boletín de la Real Academia de Bellas Artes de la Purísima Concepción, no 46, 2011, pp. 65-68.

${ }^{28}$ J. M. RAMÍREZ MARTÍNEZ, "Luis Salvador Carmona...", p. 104.

${ }^{29}$ J. NICOLAU CASTRO, “Una obra de Giacomo Antonio Ponzanelli en el comercio anticuario de Madrid", Archivo Español de Arte, no 323, 2008, pp. 303306. Modelo al que se plegó Pascual de Mena en la recoge la pintura coetánea de Mariano Salvador Maella.

2.- San Joaquín y Santa Ana, presentes como figuras emparejadas insustituibles en un programa iconográfico de afirmación mariana y de culto a la condición inmaculada de la Virgen, son tipos que revelan en sus rostros la caracterización de la edad madura o la ancianidad prematura en gestos muy estudiados y contenidos. El San Joaquín (Fig. 4) se ajusta al modelo más clásico de indumentaria no orientalizante, vistiendo túnica abotonada con cuello que se descubre en parte del torso pues el manto se echa desde

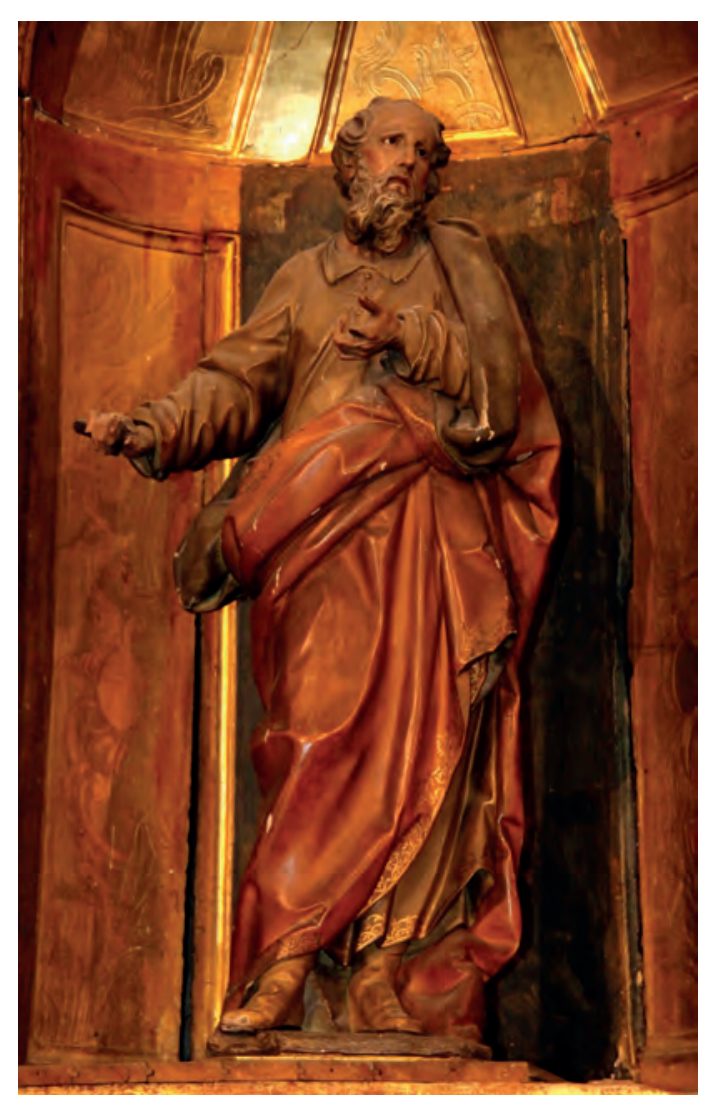

- Fig. 4. Juan Pascual de Mena. Imagen de S. Joaquín. 1759. Retablo mayor de la iglesia parroquial de S. Martín. Torrecilla en Cameros. Foto del autor.

Inmaculada que preside el retablo mayor de las monjas mercedarias descalzas o "Góngoras" de Madrid, imagen que parece experimentó alguna drástica transformación en el siglo XIX que la aleja considerablemente del estilo del escultor hasta el punto de hacernos dudar de su exclusiva autoría. 
la espalda por el hombro izquierdo y se recoge por delante bajo el brazo, abultándose a la altura de la cintura. Apoya la mano derecha en un bastón (del que hoy resta sólo la empuñadura) y coloca la izquierda en un sencillo ademán ante el pecho. Figura de una pose correcta y calma, su cabeza levemente girada luce una barba tratada con cierto movimiento y modelado efectista.

3.- Por su parte, Santa Ana, también mujer de edad, adopta una actitud serena aunque más expresiva, sujetando contra el costado izquierdo un libro abierto (como "maestra" de la Virgen) pero alzando su brazo y mano derechos a la vez que la cabeza en una mirada contemplativa (Fig. 5). En su atuendo está tocada por un pañuelo que le cubre parte del pecho y descubre la túnica ceñida por cíngulo, mientras el manto se recoge del lado izquierdo marcando con sus pliegues las líneas de la composición y movimiento.

En relación con esta iconografía de los padres de la Virgen, de 1778 será la Santa Ana encargada por el Ayuntamiento de Madrid a Pascual de Mena para su oratorio (hoy en el Museo Municipal de la ciudad), en su tipología de figura sedente como había sido interpretada junto a San Joaquín en el primer plano del gran relieve central del retablo de Santa Catalina en la iglesia de Santa María de San Sebastián, de hacia $1766^{30}$. Por otra parte, contamos con las dos imágenes de pequeño tamaño atribuidas por Nicolau Castro en la iglesia de las Carboneras de Madrid con el "garbo y finura típica del escultor" de talla seca y aristada ${ }^{31}$, si bien con distintas vestimentas. Incluso el San Joaquín de Torrecilla se puede relacionar en cuanto a la cabeza de anciano con el Padre Eterno de la parroquia de Rascafría (Madrid) ${ }^{32}$.

${ }^{30}$ L. PÉREZ DE DOMINGO, Op.cit., pp. 161 y 211.

31 J. NICOLAU CASTRO, “El escultor Juan Pascual...", pp. 202-203; L. PÉREZ DE DOMINGO, Op.cit., p. 188.

32 L. PÉREZ DE DOMINGO, Op.cit., pp. 199220. Imagen procedente de la cartuja de El Paular. Retablos dedicados a María Inmaculada se componen

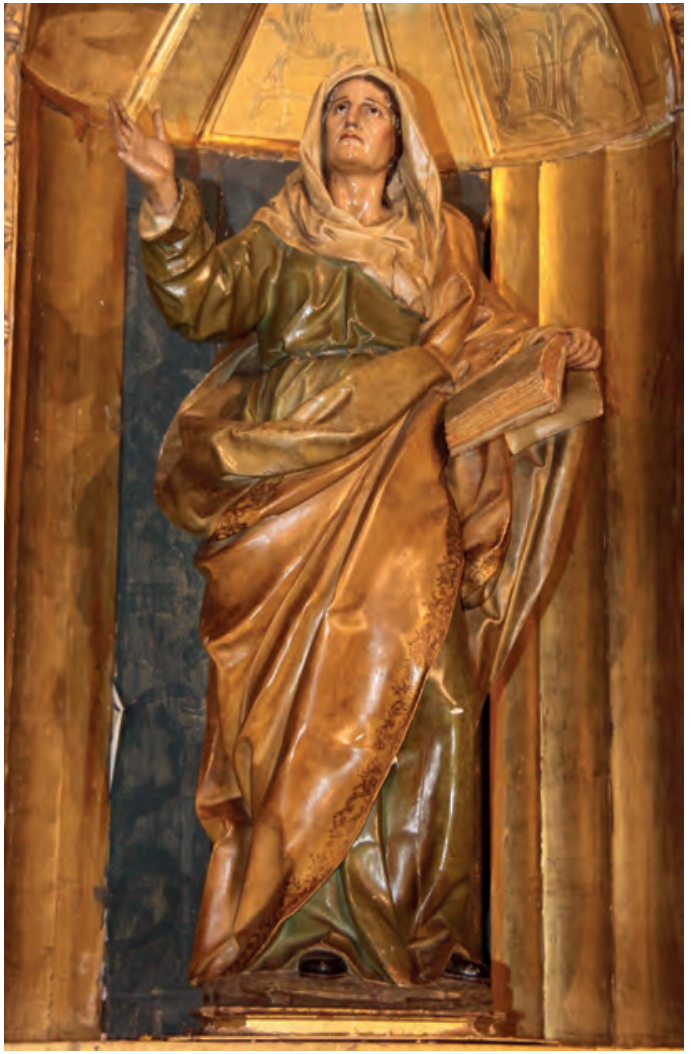

- Fig. 5. Juan Pascual de Mena. Imagen de Sta. Ana. 1759. Retablo mayor de la iglesia parroquial de S. Martín. Torrecilla en Cameros. Foto del autor.

4.- San Francisco de Asís (Fig. 6). Esta imagen de bulto culminaba el programa iconográfico al dar presencia al santo fundador y emblema de la Orden Seráfica. Si originalmente estuvo por encima del transparente de la Inmaculada en el retablo mayor del convento, hoy se encuentra apartada del culto en el museo parroquial dentro de una hornacina que a su vez perteneció a la caja dieciochesca del retablo mayor y que albergó la efigie de San Martín entronizado. Así pues, encontramos en esta decorosa imagen una iconografía nueva que hasta ahora no conocíamos dentro del repertorio de Pascual de

preferentemente con el trío iconográfico y los progenitores también se incluyen, como por ejemplo en las hornacinas del mencionado retablo de la Inmaculada de la villa de Falces (Navarra), debidas esta vez a las gubias de Fernando del Cid, un escultor madrileño apenas conocido y sorprendente imitador de Juan Pascual de Mena, y que se bendicen en 1771, véase R. FERNÁNDEZ GRACIA, Op.cit., p. 260. 


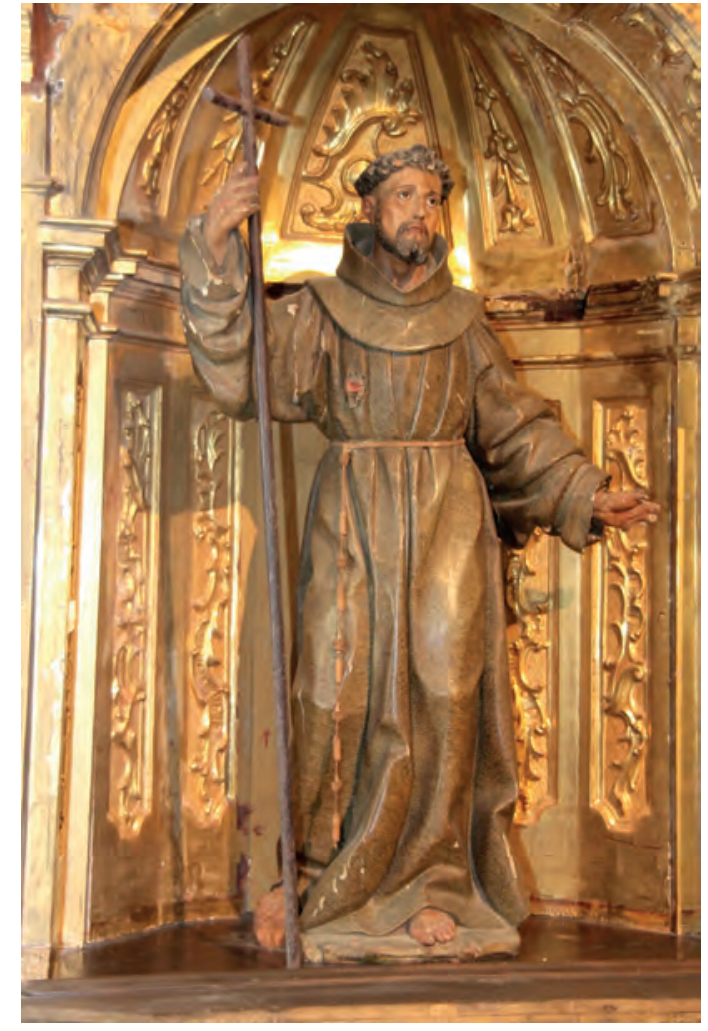

- Fig. 6. Juan Pascual de Mena. Imagen de S. Francisco de Asís. 1759. Museo de la iglesia parroquial de S. Martín. Torrecilla en Cameros. Foto del autor.

Mena, salvo el San Francisco de Asís mencionado por don Antonio Ponz en la sacristía de los franciscanos de San Gil de Madrid, que se ha querido identificar con la imagen de San Francisco del Museo Nacional de Escultura de Valladolid y que resulta tan distinta iconográficamente ${ }^{33}$. Sin apenas referencias

${ }_{33}$ Anotado en su Viage de España por Antonio Ponz, lo seguirá citando el diccionario de ilustres profesores de Agustín Ceán en ese mismo lugar pero no así Pascual Madoz en su Diccionario, pues hubo de ser uno de los bienes desamortizados que pasara al Museo de la Trinidad de Madrid. J. AGAPITO Y REVILLA, “Obras nuevas y nuevamente expuestas en el Museo Nacional de Escultura", Boletín de la Academia de Bellas Artes de Valladolid, no 14, 1935, pp. 163-185. También L. PÉREZ DE DOMINGO, Op.cit., pp. 195-196. Lo cierto es que en Valladolid dentro de la iglesia de San Andrés existen dos retablos con esculturas atribuidas a Juan Pascual de Mena, como son un San Antonio de Padua y un San Francisco de Asís, ambas en composición escenográfica, arrodilladas y de perfil, ejecutadas antes de 1780 bajo patrocinio del franciscano Fray Manuel de la Vega y Calvo, predicador y comisario general de Indias, véase comparativas, el San Francisco de Torrecilla en Cameros asume el tipo característico aquí requerido por su específica representación como "abanderado" que dice el documento, es decir, enarbolando una cruz y no como santo glorioso en éxtasis o recibiendo la estigmatización. Su rostro no refleja los rasgos excesivamente acentuados y patéticos de las esculturas que Salvador Carmona dedica a este santo y tan consideradas en su portentoso arte como son los conservados en Valladolid, Olite (Navarra) y Estepa (Sevilla). Pascual de Mena muestra al santo descalzo y hace visibles los estigmas de las llagas bajo una expresión postulante y de mirada elevada y beatífica. Su composición abierta con el brazo derecho levantado y empuñando una vara cruciforme se compensa con el izquierdo llevado hacia abajo y extendida la mano basculando el peso del cuerpo sobre la pierna izquierda algo adelantada. El hábito se ciñe en plegados largos y quebrados hasta el suelo desde la amplia cogulla y se recogen por el cordón natural que lo ciñe a la cintura. Lamentablemente es la imagen con mayor deterioro, al faltarle en ambas manos los dedos y presentar numerosos roces y fisuras.

5.- San Juan Bautista (Fig. 7). Responde su presencia en el programa de representaciones por ser el santo que da el nombre de pila al fundador don Juan Manuel. Lejos del enérgico Bautista de San Fermín de los Navarros de Madrid, en actitud declamatoria como predicador, este de Torrecilla se adscribe a modelos usuales de representación que ya pusiera en boga Luis Salvador Carmona bajo un concepto más barroco de las expresiones siguiendo el patrón del que su maestro Villabrille y Ron tallara para el retablo mayor de la catedral de Badajoz en $1717^{34}$.

J. M. TRAVIESO, "Theatrum: San Antonio de Padua y San Francisco de Asís, obras de un escultor conocido por la Fuente de Neptuno de Madrid", 2015, consultado el 27 de julio de 2016. URL: http://domuspucelae. blogspot.com.es/2015/01/theatrum-san-antonio-y-sanfrancisco.html.

${ }^{34}$ Un precedente muy señalado sería el "Sanjuanito" de Úbeda (Jaén), obra de Miguel Ángel, en lo tocante a la postura de la pierna, forma prodigada en la escultura 


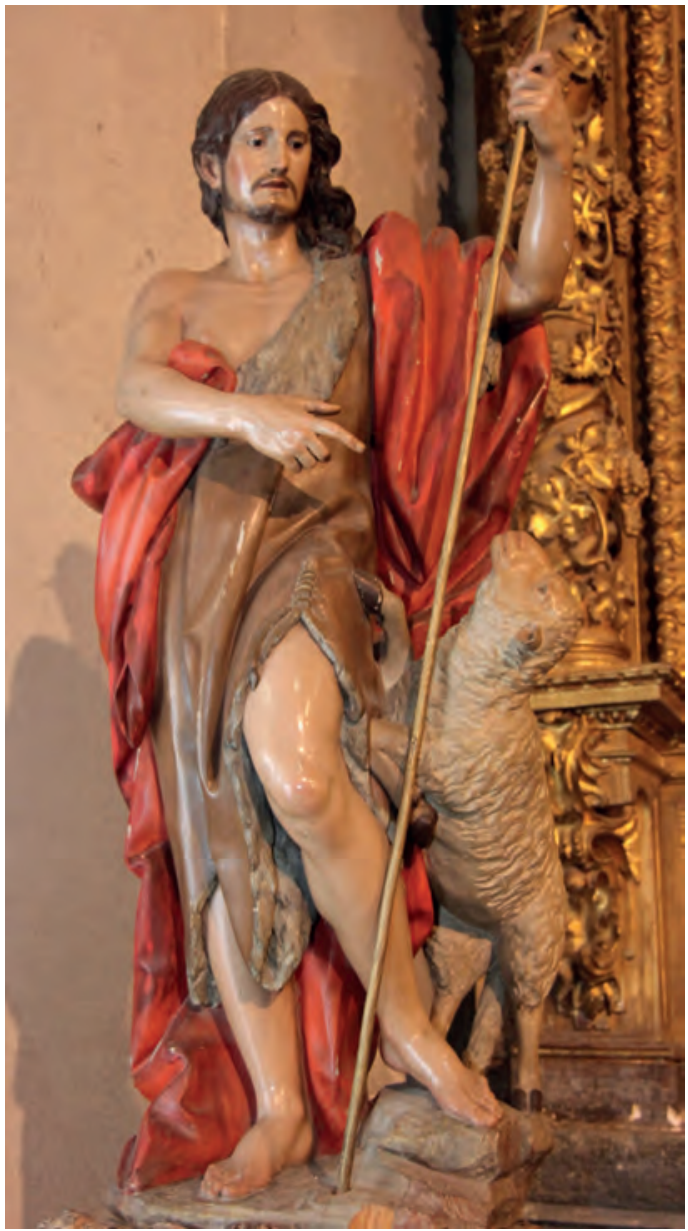

- Fig. 7. Juan Pascual de Mena. Imagen de S. Juan Bautista. 1759. Iglesia parroquial de S. Martín. Torrecilla en Cameros. Foto del autor.

Como siempre, la composición de Pascual de Mena suaviza los excesos expresivos y aploma una figura vigorosa, en contraposto muy elegante con el pie izquierdo apoyado en una roca más alta, haciendo escalón, que obliga a una efectista flexión de la rodilla y su lucimiento anatómico; y donde se sitúa el simbólico cordero, levantado sobre sus patas traseras, en su representación naturalista, y al que señala con su mano derecha a la vez que le dirige una serena mirada. El manto rojo refuerza por detrás la composición sin llegar a envolver la figura semidesnuda del

andaluza en las representaciones infantiles del profeta y que también vemos en la imagen de San Juan Bautista de la cartuja madrileña de El Paular, obra de madurez del sevillano Pedro Duque Cornejo $(+1757)$ dentro del conjunto decorativo realizado en 1725 , y que tal vez llegó a conocer bien Juan Pascual de Mena. precursor, vestida con el chamelote que apenas cubre su busto, brazos y piernas. La cabeza es toda una lección de belleza juvenil, de incipiente barba y acentuada por la melena volada hacia un lado y que preconiza la cabeza de mayor fuerza expresiva del ya citado San Eloy de los plateros de la iglesia de San José de Madrid; y cuya mirada penetrante se repite en otras esculturas varoniles del artista, como en las de los santos Crispín y Crispiniano de la iglesia de San Nicolás de Bilbao.

El San Juan Bautista de Torrecilla es un modelo que Juan Pascual de Mena asumió como propio y el impacto de esta potente imagen pudo hacer posible su imitación en el San Juan Bautista de la iglesia de Santiago el Real de Logroño, de aparente menor calidad y aún por estudiar. Y, aunque relacionable con el San Juan Bautista de Pedro Bernardo (Ávila), la distancia formal entre ambas induce a pensar en un buen imitador del maestro como es el escultor Fernando del Cid, a quien tal vez haya que atribuir la abulense ${ }^{35}$.

6.- San Antonio de Padua (Fig. 8). Santo insustituible y muy popular dentro de la orden franciscana, es una de las advocaciones más representadas por Pascual de Mena a lo largo de su carrera como imaginero y en la que consiguen modelos tan hermosos, a juicio de Nicolau Castro, como el prototípico de la iglesia de San Antón de Bilbao ${ }^{36}$ o el recientemente identificado por nosotros de la iglesia de las Calatravas de Madrid, antes dado graciosamente a Salvador Carmona ${ }^{37}$. En su modalidad de santo no glorificado, el San Antonio de Torrecilla es una figura plan-

${ }^{35}$ J. A. SÁNCHEZ RIVERA, "El escultor Fernando del Cid. Algunos datos sobre su vida y su actividad artística", Archivo Español de Arte, no 331, 2010, pp. 249266.

36 J. NICOLAU CASTRO, "El escultor Juan Pascual...", p. 199.

${ }^{37}$ A. J. DÍAZ FERNÁNDEZ, "El San Antonio de Padua de las Calatravas de Madrid, obra del escultor académico Juan Pascual de Mena", Anales del Instituto de Estudios Madrileños, no 53, 2013, pp. 277-289. 


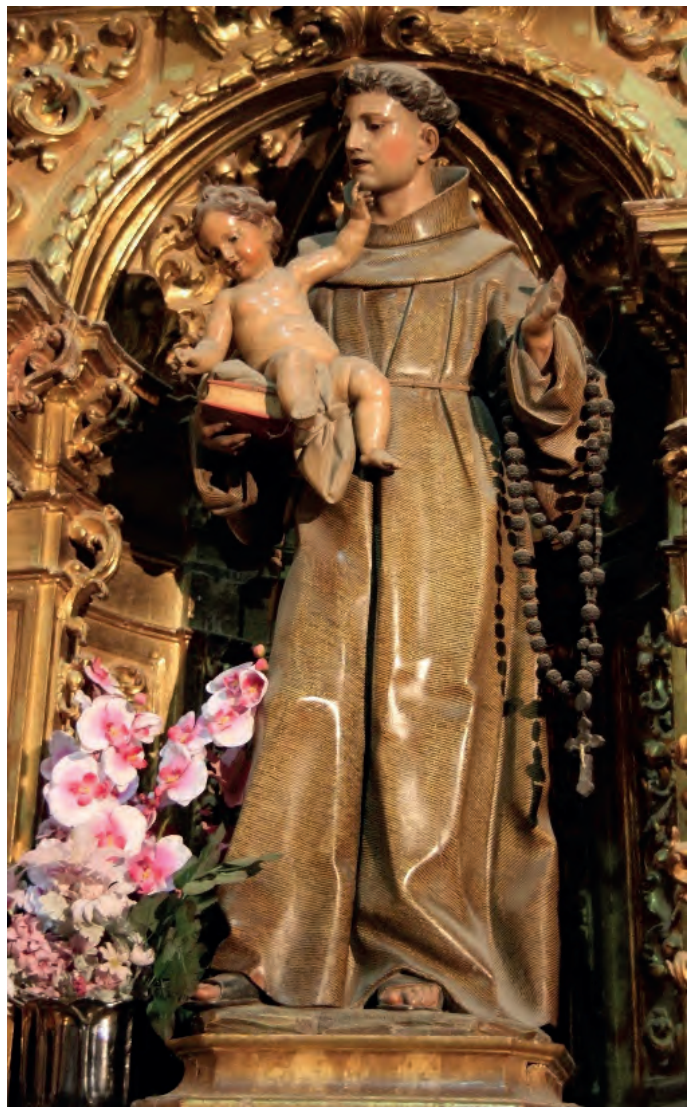

- Fig. 8. Juan Pascual de Mena. Imagen de S. Antonio de Padua. 1759. Iglesia parroquial de S. Martín. Torrecilla en Cameros. Foto del autor.

tada sobre un suelo rocoso y que sostiene con su mano derecha un libro sobre el que se sienta el Niño Jesús ${ }^{38}$. Comparativamente, la talla se relaciona bastante con la que adorna el retablo de la Piedad en la iglesia bilbaína de San Nicolás, que es su precedente cronológico. De esbelto canon, destaca la cabeza, todo un ejemplo de perfección clásica, juvenil y apolínea que embellece la efigie. En este punto de caracterización estaría en consonancia con el ideal de belleza masculina que manifiesta el San Antonio de la citada iglesia de las Calatravas. Del mismo momento, pues Nicolau lo fecha con anterioridad a 1760, es el más pequeño de las monjas agus-

38 Parece suscitarse una confusión respecto a la imagen de San Antonio de Padua, pues además de ésta que procede del convento franciscano debió existir alguna otra en la parroquia de Ntra. Sra. de las Vegas de Torrecilla, de igual belleza, véase J. M. RAMÍREZ MARTÍNEZ, Torrecilla en Cameros..., p. 34, y de lo que se hace eco L. PÉREZ DE DOMINGO, Op.cit., p. 218. tinas de Santa Úrsula de Toledo, dentro de la misma tipología ${ }^{39}$.

Por su parte, la figura del Niño es sin duda uno de los elementos más personales de la mano maestra de Pascual de Mena y una de las señas de identidad del escultor plasmando con sencilla ternura la esencia de lo infantil en su forma y fondo. Se advierte un tratamiento delicado pero muy naturalista en los gestos y actitudes y un agradable estudio anatómico de sus desnudos, pues a diferencia de las de Salvador Carmona, también deliciosas, las de Pascual de Mena no suelen cubrirse mostrando así la belleza y gracia de sus pequeños cuerpos. Este es un niño que se incorpora sobre el libro que sostiene el santo, trazando una línea abierta con los dos brazos desde la barbilla buscando también con su mirada la del fiel. Un niño que será de igual forma pensado, aunque puesto en el otro lado, en el San Antonio de Padua de la iglesia madrileña de Santa Cruz, hoy sólo conocido a través del grabado y datado a partir de $1767^{40} ; \mathrm{y}$ sin olvidar la misma colocación del lado izquierdo en el San Antonio de Padua de las Calatravas de Madrid. Un niño tan vivaz y enérgico como el que portan el San Antonio de la iglesia de San Nicolás o el de la iglesia de San Antón, ambas en Bilbao. Un Niño Jesús cuyo modelo es a su vez una clara identificación de su estilo en las representaciones de San José talladas por Juan Pascual de Mena, siendo la más extraordinaria la del Santo Patriarca de las carmelitas descalzas de Talavera de la Reina (Toledo) ${ }^{41}$.

39 J. NICOLAU CASTRO, "El escultor Juan Pascual...", p. 199. Imagen que se encuentra en paradero desconocido una vez que recientemente el convento ha sido cerrado y emigrada su corta comunidad.

${ }^{40}$ M. AGULLÓ COBOS (dir.), Arte y devoción: estampas de imágenes y retablos de los siglos XVII y XVIII en iglesias madrileñas, Madrid, 1990, p. 55. Se indica estar dibujado y grabado por Juan Antonio Salvador Carmona e "inventado por Juan Pascual Mena", por encargo de su cofradía y dedicado a $\mathrm{D}^{\mathrm{a}}$ Alfonsa de Silva, duquesa del Infantado y de Pastrana.

${ }^{41}$ J. NICOLAU CASTRO, "Dos posibles obras desconocidas de Juan Pascual de Mena en Talavera de la Reina", Archivo Español de Arte, no 177, 1972, pp. 63-66. 
En lo fundamental hemos considerado el conjunto escultórico de Juan Pascual de Mena para los tres retablos del desaparecido convento franciscano de Torrecilla en Cameros realizado en torno a $1758-59$, pero si revisamos las atribuciones en la misma parroquia no podemos compartir la asignación al escultor francés Roberto Michel de otra de las magníficas esculturas madrileñas de esta iglesia, la Virgen del Rosario, fechada en 1759, ni dejar por anónimas otras parcialmente documentadas como el San Martín titular de la iglesia ${ }^{42}$ y una no mencionada hasta ahora, la de San Nicolás Obispo (acaso confundida con San Blas), que se expone en el museo parroquial. Así pues, detengámonos en las tres esculturas que son ajenas al consabido conjunto de procedencia conventual.

7.- Ntra. Sra. del Rosario (Fig. 9). La imagen se expone en un pequeño retablo adosado al primer pilar de la epístola en la nave de la iglesia. Se levanta sobre un pequeño trono de nubes que asientan en una sencilla peana ochavada. Deja ver las punteras de sus zapatos bajo las largas caídas y pliegues quebrados de su túnica roja mientras el manto azulado se tercia por delante en diagonal, ambos adornados con motivos y orlas dorados. Descubre su torso extendiendo el brazo y mano derechos hacia adelante en la actitud de entrega del rosario, mientras que sostiene sobre su brazo izquierdo a un Niño recostado en su regazo sobre la mano izquierda, en movida actitud y perdida la mirada. La cabeza de la Virgen se dirige a ese lado envuelta parcialmente por el pañuelo que de detrás hacia delante deja asomar elegante su cabellera levemente ondulada. El rostro es

42 J. G. MOYA VALGAÑÓN, Op.cit., pp. 157-169. Este autor obtiene algunos datos del libro de fábrica parroquial de 1743, y halla que la imagen titular de San Martín es de 1781, y también menciona algunas otras imágenes de procedencia madrileña como San Antonio de Padua, San Sebastián que sitúa entre 1775-1782 con otras desaparecidas de San Roque y un Santo Ángel de la Guarda; más otra Virgen del Rosario (distinta a la aquí atribuida), San José, San Joaquín y Santa Ana y Santa Catalina de Sena. Las más, regalo de D. Nicolás Manso de Velasco, Marqués de Ribas del Jarama, véase J. M. RAMÍREZ MARTÍNEZ, Torrecilla en Cameros..., p. 84.

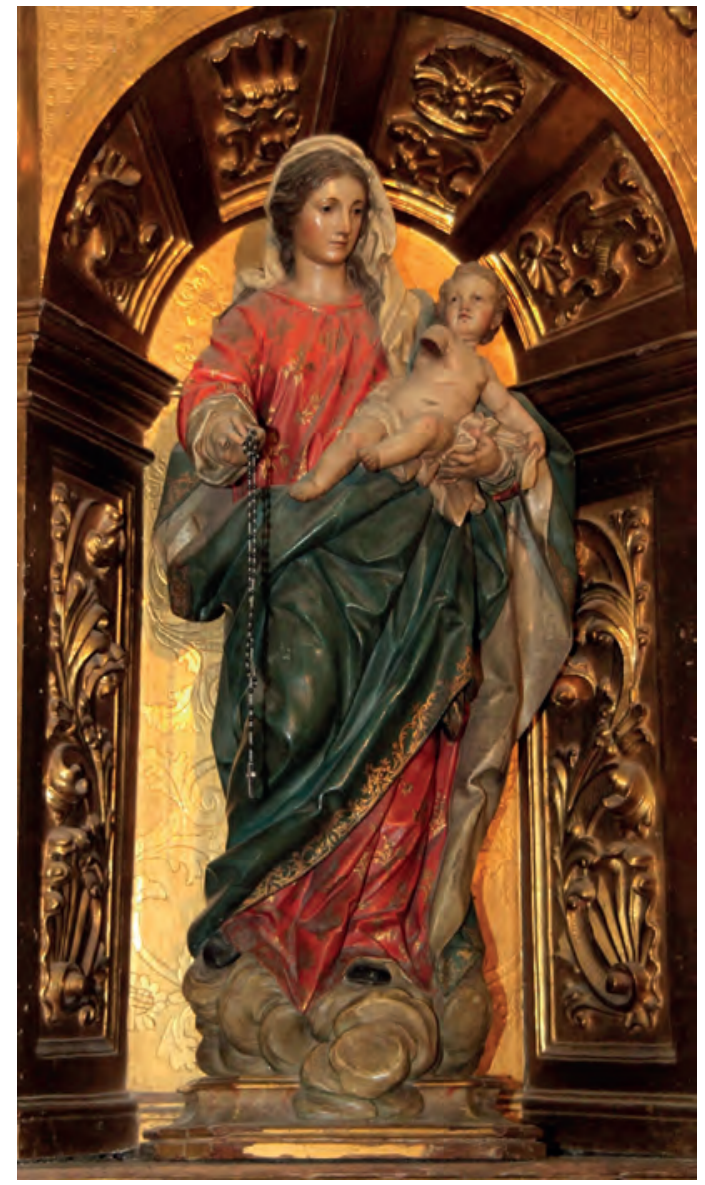

- Fig. 9. Juan Pascual de Mena. Imagen de Ntra. Sra. del Rosario. Ca. 1759. Iglesia parroquial de S. Martín. Torrecilla en Cameros. Foto del autor.

ovalado, asimilado al de una joven de delicadas facciones y rasgos idealizados por un perfecto clasicismo y una mirada absorta dirigida hacia el fiel. La existencia de una cofradía y su libro de cuentas nos informa que los mayordomos don Alonso Tomás de Bilbao la Vieja y don Martín Sorzano Collado eran naturales de la villa de Torrecilla pero vecinos de Madrid en 1758, cuando donan a la imagen un estandarte para las procesiones. También don José de Segura, vecino de Madrid, donó un juego de seis candeleros de plata y un frontal; pero más importante es la limosna de 1.000 reales que ofreció Alonso Tomás de Bilbao " $\mathrm{p}^{\mathrm{a}}$ hacer una ymagen de nra señora del Rosario de scultura en Madd. a su cuid ${ }^{\circ}$. como alc[ald]e q. es este año de la cof $^{\text {a }}$. fundada en esta villa del SSmº ${ }^{\text {. Rosa- }}$ rio", ayuda considerable pues cubrió en par- 
te los "mil y seis cํos. reales de $\mathrm{v}^{\mathrm{o}} \mathrm{n}$. q. costo una ymagen de scultura intitulada del Rosario, q. se trajo de Madrid p $\mathrm{p}^{\mathrm{a}}$. colocarla en la capilla de su cof ${ }^{a}$. desta villa" ${ }^{43}$. Aquí, la escultura, de pequeñas proporciones, alcanza igualmente un resultado estético inconfundible. En principio, su relación con la Virgen del Rosario de Antezana de Foronda (Álava) de $1763-67^{44}$ o la misma Virgen del Rosario de la iglesia cántabra de Limpias de hacia 1754, fecha del retablo ${ }^{45}$, nos disuade de cualquier atribución a artista que no sea Juan Pascual de Mena. La imagen fue obrada, por tanto, en Madrid y al mismo tiempo que las del convento.

8.- San Martín obispo (Fig. 10). Esta imagen aparece citada en relación con una decidida reforma del retablo mayor en 1781 que afectó a todo el cuerpo inferior de la estructura renacentista, haciéndose un tabernáculo de espejos, y también a la caja u hornacina principal donde colocar la nueva imagen del titular, que se dice traída desde Madrid; y todo bajo la dirección del maestro de arquitectura Feliciano Pérez Ortiz ${ }^{46}$, ensamblador

${ }^{43}$ APTC, Libro del Rosario 1730 o "Libro nuebo de la Cofradia de N. S. del Rosso․ q- se empieza â escribir este año de 1730 sea a honra y Gloria de Dios y de su Santmª Madre Amên", fol. 101-102v. Siendo abad de la cofradía D. Juan Bernardo de Azpeytia en 27 de marzo de 1759. Pero por los gastos de otras partidas parece que la devoción del Rosario, una imagen antigua de vestir, que es sustituida, que no reemplazada, por una imagen nueva traída de Madrid, se hacía en una capilla propia de la iglesia de San Martín que estaba siendo adecentada y decorada entonces con aprobación de la visita de 1762 (Ibídem, fol. 106).

${ }^{44}$ F. TABAR ANITUA, Barroco importado en Álava. Escultura y pintura. Vitoria-Gasteiz, 1995, pp. 71-73. ÍDEM, "Modelos cortesanos para esculturas y pinturas neoclásicas en Álava", ONDARE, no 21, 2002, pp. 243250 .

${ }^{45}$ L. PÉREZ DE DOMINGO, Op.cit., p. 215 y 219.

${ }^{46}$ APTC, Libro de fábrica de 1743 o "Libro de quentas de la fabrica del Sr. San Martin desta Villa de Torrecilla de los Cameros que da principio a escribirse en este presente año de mil setecientos y quarenta y tres", fols. 207r-208v. En las cuentas de la mayordomía del año 1782, dadas por D. Manuel de Artabeytia, de los 18.708 reales habidos en las arcas parroquiales se descuenta lo gastado en hacer el nuevo tabernáculo o sagrario de retablos y también escultor, que trabaja en el último cuarto del siglo XVIII en lugares de la comarca de los Cameros, especializado en reformas de sagrarios y tabernáculos y con el que colabora, en algunos casos, el dorador de Torrecilla Manuel Mazo.

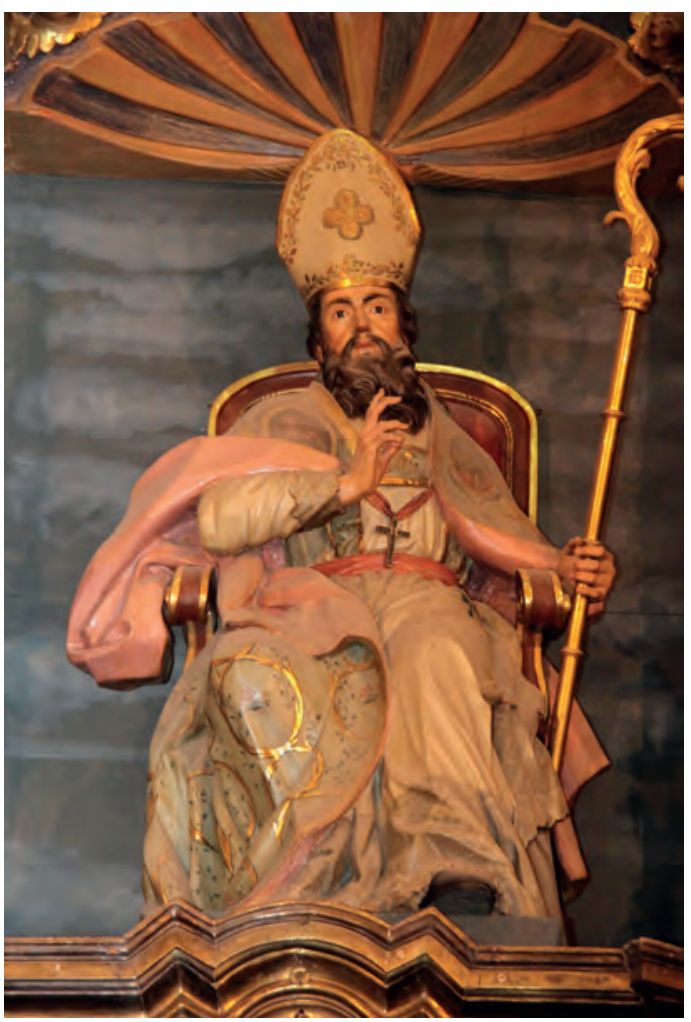

- Fig. 10. Juan Pascual de Mena. Imagen de S. Martín Obispo. 1781. Retablo mayor de la iglesia parroquial de S. Martín. Torrecilla en Cameros. Foto del autor.

La imagen del santo obispo francés del siglo IV se muestra in catedra, sedente, vestido de pontifical y tocado con la mitra de su dignidad, bellamente decorada. Con un leve giro de su torso, que hace bajar el hombro izquierdo, sujeta con esta mano el báculo de su ministerio y, con el brazo derecho, recogida hacía sí levanta la mano en actitud de bendecir. Indicadores de su mediana edad, los

con tramoya y cristales azogados y su dorado, el trono o canapé tallado en nogal, nueva peana y la efigie de San Martín, la cual costaba 1.268 reales incluidos cajón, encerados, cuerdas y clavos de su transporte y otros 710 reales de su conducción desde Madrid en dos machos por dos hombres. 
cabellos y luenga barba son oscuros y aunque ésta se agita suavemente, la cabeza, algo inclinada, muestra un rostro respetable y de mirada perdida. El tratamiento del ropaje es sumario en pliegues rectos que se quiebran sobre los pies de la figura, revelando la textura del delicado alba que le viste. La capa pluvial ofrece mayor juego en los vuelos y dobleces envolviendo con majestad la figu$\mathrm{ra}, \mathrm{y}$, aunque bien asentada sobre los hombros, en cambio, se coloca sobre la rodilla derecha mostrando su envés ornamentado en tanto que se agita con el movimiento del brazo derecho dejando ver el revés rosado en grandes planos de talla. Esta capa ofrece ciertos detalles de policromía imitando un terno rico con medallones pintados a modo de historias bordadas sobre los hombros representando a San Pablo y a San Pedro, y el resto con rameados rítmicos dorados en círculos entrelazados y alternando con minuciosos dibujos de hojas y flores.

Dentro del repaso a su obra en Torrecilla, Pérez de Domingo no menciona esta imagen como de Juan Pascual de Mena, quizás porque nadie se la haya atribuido anteriormente al escultor toledano, tal vez por lo avanzado de su fecha. Cierto que en 1781 Pascual de Mena contaría con setenta y cuatro años de edad, aunque las facultades del que había sido Director General de la Academia de San Fernando entre 1771 y 1774 para poder esculpir imagen tan interesante no debían de estar mermadas si sabemos que, entre 1778 y 1779, entrega la obra complementaria al retablo de la capilla de San Ildefonso de la catedral de Toledo ${ }^{47} \mathrm{y}$, en diciembre de 1781, se documenta el encargo de los premonstratenses de Ciudad Rodrigo (Salamanca), tallando para su retablo mayor una Asunción de la Virgen, hoy en el presbiterio de la catedral mirobrigense ${ }^{48}$. De estos años es la imagen de San José de la capilla de la Presentación de la catedral de Burgos

47 J. NICOLAU CASTRO, "El escultor Juan Pascual...", pp. 209-210.

${ }^{48}$ M. HERNÁNDEZ VEGAS, Ciudad Rodrigo: la catedral y la ciudad, Valencia, 2012, T. I, p. 183.
(1782), que más parece realizada sobre un modelo suyo, pero también las estatuas de piedra de San Isidro y Santa María de la Cabe$z a$ para la fachada de la colegiata de San Isidro de Madrid (1782), y, entre 1781 y meses antes de su muerte, en abril de 1784, estaría esculpiendo en mármol de Montesclaros el imponente dios Neptuno y los dos caballos marinos de la fuente del Paseo del Prado de Madrid, su última gran empresa artística ${ }^{49}$. Por supuesto, el San Martín de Torrecilla está muy lejos del San Martín en gloria que Salvador Carmona labró para el retablo mayor de Lesaca (Guipuzcoa), pues este que atribuimos desde ahora a Pascual de Mena es más contenido y reposado que incluso el propio San Marcos de su mano, también estatua sedente, de su parroquia de Madrid, labrado en 1757, aligerado de gestos barroquizantes pues la deriva academicista está consolidada a finales del siglo XVIII.

9.- San Nicolás de Bari (Fig. 11). Por su indumentaria pontifical a la que se añade el palio arzobispal de cruces negras, de origen oriental, sin más atributos que el libro (que por su posición horizontal y cerrado pudo haber sujetado las tres bolas de oro que simboliza uno de sus señalados milagros) y un perdido báculo que empuñaría en su mano derecha, bastante dañada y con falta de dedos, podríamos identificar la talla con San Nicolás de Bari y no con otro obispo santificado. De su existencia no hay rastro documental y pudo haber recibido culto en alguna de las otras tres iglesias que tuvo Torrecilla en Cameros y que a lo largo del siglo XIX terminaron por reunirse en la principal, la de San Martín, con todos sus enseres. Su actual condición de figura museística indica que no recibía culto en origen en esta parroquia, y de ahí su presumible llegada desde otro lugar sagrado de esta villa. A falta de un dato concluyente, podríamos relacionarla, aun en su más severa composición, con el San Benito de la iglesia de San Marcos de Madrid en cuanto a la misma actitud y colocación de

${ }^{49}$ L. LÓPEZ DOMINGO, Op.cit., pp. 190, 164 y 135145. 


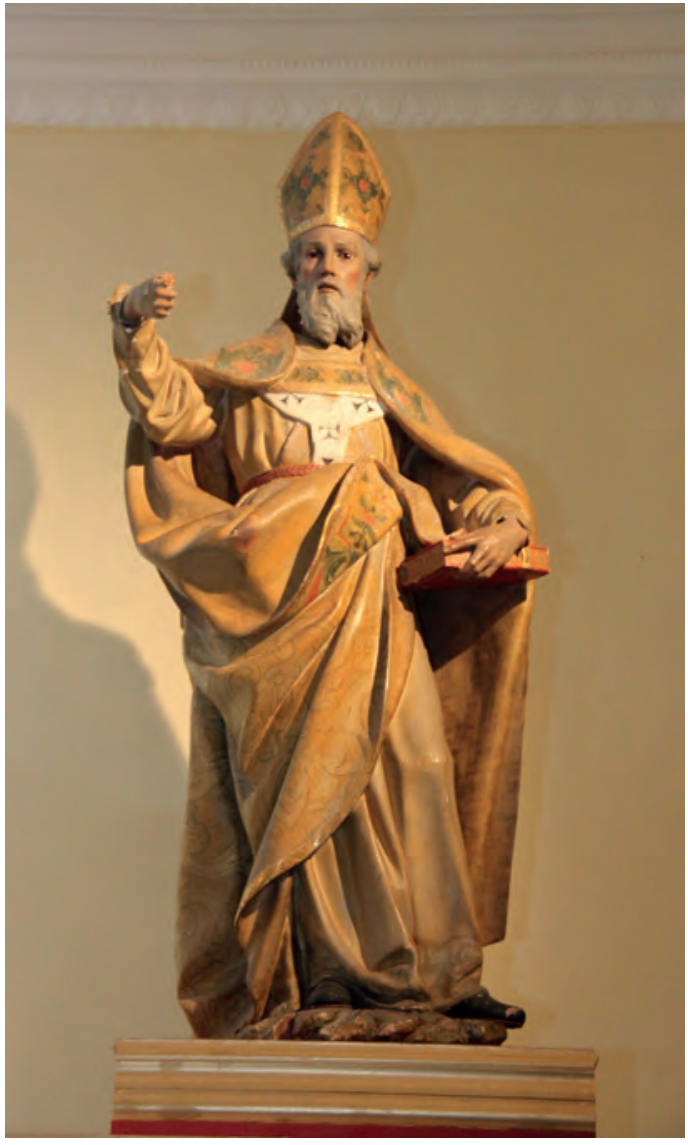

- Fig. 11. Juan Pascual de Mena. Imagen de S. Nicolás de Bari (?). Hacia 1775. Museo de la iglesia parroquial de S. Martín. Torrecilla en Cameros. Foto del autor.

las manos, aunque su rostro acusa una menor fuerza expresiva respecto a la efigie del santo benedictino, si bien hay intensidad en la mirada. Estaríamos ante una imagen algo más depurada en su movimiento y actitud, datándola hacia 1775, lejos de la viveza de las imágenes de San Nicolás y San Blas de la iglesia bilbaína de San Nicolás (1755), o del obispo que corona uno de los dos retablos del trascoro de San Millán de la Cogolla (hacia 1766) y poco que ver con el San Eloy en gloria de la iglesia madrileña de San José (1764). Aunque es figura de menos vigor, está resuelta con la gravedad, la corrección artística y el aplomo de la estatuaria clasicista a que nos tienen acostumbrado Juan Pascual de Mena, cuyo estilo sobrio se diferencia, por ejemplo, de una figura similar como la de San Geroteo de su capilla en la catedral de Segovia, tallada en 1770 por Manuel Ade- ba Pacheco, otro de los académicos madrileños pero de formación italiana. El rostro del San Nicolás es bello y sereno, mostrando un modo de tallar las barbas coincidente con lo visto en el San Joaquín y también en el San Martín de esta misma iglesia. Nicolau Castro ve esta peculiaridad de modelado casi táctil en las barbas del San Benito de la iglesia de San Marcos y también en el voluminoso $\mathrm{Pa}$ dre Eterno de las Góngoras ${ }^{50}$, ambas en Madrid.

Juan Pascual de Mena cumplió encargos para templos de La Rioja, de mayor y menor categoría votiva. Y se hace más que probable su intervención en otras localidades de importancia y no dudamos que en capitales como en Logroño o Calahorra, donde hay esculturas de procedencia madrileña todavía por investigar y determinar su autoría, pese a los empeños realizados por encauzar manifestaciones de la escultura dieciochesca cortesana en el entorno de Luis Salvador Carmona $^{51}$. Al menos se reconoce documentalmente su participación en los dos excelentes retablos del citado trascoro del monasterio de Yuso de San Millán de la Cogolla, de hacia 1766, dedicados a Santa Potamia y Santa Oria o Aurea y con seis esculturas más ${ }^{52}$, pero también en Ortigosa de Cameros se le atribuye la imagen de Santa Lucía, realizada a partir de $1770^{53}$.

$\mathrm{Y}$ aunque sin documentación por ahora, no estaría lejos de su depurado estilo la

50 J. NICOLAU CASTRO, "El escultor Juan Pascual...", p. 202.

${ }^{51}$ J. M. RAMÍREZ MARTÍNEZ, "Luis Salvador Carmona...", pp. 97-113. Esculturas localizadas en las iglesias riojanas de Lumbreras, Calahorra y Murillo de Río Leza.

${ }^{52}$ J. M. RAMÍREZ MARTÍNEZ, “Juan Pascual de Mena en San Millán...", pp. 301-307. El trascoro es obra de Francisco Bisou en un acusado estilo rococó y las esculturas secundarias representan a S. Braulio, S. Felices, S. Aselo, S. Geroncio, S. Citonato y S. Sofronio.

${ }^{53}$ J. M. RAMÍREZ MARTÍNEZ, "Juan Pascual de Mena en Ortigosa de Carneros", Revista Siete Ríos, Logroño, no 6, 1997, p. 15. Imagen que se custodia hoy en la iglesia parroquial de San Martín, procedente de la ermita de su advocación. 
devota imagen de María Magdalena de la parroquia de Muro en Cameros, que bien se le pudiera atribuir sin reservas, como también habría que restituir definitivamente la autoría de las dos tallas que flanquean el gran lienzo de la Inmaculada Concepción, de José de Beges, en la sacristía de la catedral de Calahorra, que representan a San Juan de Capistrano y a San Pedro Arbués, costeadas por el obispo don Juan Miguel Mortela antes de 1770 y que definen el carácter decoroso y refinado de su escultura.

Como conclusión, cabe decir que Juan Pascual de Mena, en sus obras y a través de sus comprometidas enseñanzas, implantó un estilo nuevo de tendencia academicista que desde 1770 se afianzó con la nueva generación de escultores cortesanos formados en la Academia de Bellas Artes de San Fernando y que dejaron su impronta diseminada no sólo en templos riojanos. El conjunto escultórico, hoy descontextualizado, que Juan Pascual de Mena esculpió para el extinguido convento franciscano de Torrecilla en Cameros en 1759, más otras imágenes fruto de nuevos encargos parroquiales, demuestra la solvencia artística de este escultor de origen toledano que tuvo un indiscutible protagonismo en el devenir de la escultura española del siglo XVIII a la par y en competencia con su correligionario Luis Salvador Carmona, de quien se desmarca sensiblemente por cultivar un estilo sobrio y elegante que dota a sus esculturas religiosas de notable belleza y dignidad clásica, no exenta de sentimiento, lo que le convierten en la otra referencia artística de la escultura de su época, la que durante la segunda mitad de la centuria encauza desde la corte madrileña la nueva orientación formal que desemboca ineludiblemente en la plástica neoclásica.

\section{BIBLIOGRAFÍA}

AGAPITO Y REVILLA, J., “Obras nuevas y nuevamente expuestas en el Museo Nacional de Escultura", Boletín de la Academia de Bellas Artes de Valladolid, no 14, 1935, pp. 163-185.
AGULLÓ COBOS, M. (dir.), Arte y devoción : estampas de imágenes y retablos de los siglos XVII y XVIII en iglesias madrileñas, Madrid, 1990.

COLLAR DE CÁCERES, F., "El sepulcro del obispo Idiáquez y sus autores: José Galván y Carlos de la Colina", Boletín del Seminario de Arte y Arqueología, , no 49, 1983, pp. 503508.

DÍAZ FERNÁNDEZ, A. J., "Notas para la biografía del escultor Juan Pascual de Mena", Boletín del Seminario de Arte y Arqueología, no 52, 1986, pp. 501-508.

DÍAZ FERNÁNDEZ, A. J., "El San Antonio de Padua de las Calatravas de Madrid, obra del escultor académico Juan Pascual de Mena", Anales del Instituto de Estudios Madrileños, no 53, 2013, pp. 277-289.

FERNÁNDEZ GRACIA, R., La Inmaculada Concepción en Navarra: Arte y devoción durante los siglos del Barroco. Mentores, artistas e iconografía, Pamplona, 2004.

GARCÍA GAÍNZA, M. C., “Nuevas obras de Luis Salvador Carmona", Goya : Revista de Arte, nº 221, 1991, pp. 277-283.

HERNÁNDEZ VEGAS, M., Ciudad Rodrigo: la catedral y la ciudad, Valencia, 2012, t. I.

MARTÍN GONZÁLEZ, J. J., Escultura barroca en España (1600-1770), Madrid : Manuales Arte Cátedra, 1983.

MOYA VALGAÑÓN, J. G., "Sobre algunas esculturas cortesanas dieciochescas", Cuadernos de Investigación Histórica Brocar, no 14,1988 , pp. $157-169$

NICOLAU CASTRO, J., “Dos posibles obras desconocidas de Juan Pascual de Mena en Talavera de la Reina", Archivo Español de Arte, no 177, 1972, pp. 63-66.

NICOLAU CASTRO, J., "El escultor Juan Pascual de Mena", Goya : Revista de arte, no 214, 1990, pp. 194-204.

NICOLAU CASTRO, J., “Una obra de Giacomo Antonio Ponzanelli en el comercio anticuario de Madrid", Archivo Español de Arte, no 323, 2008, pp. 303-306. 
NICOLAU CASTRO, J., "Esculturas del siglo XVIII en la parroquia de Güeñes (Vizcaya)", Boletín de la Real Academia de Bellas Artes de la Purísima Concepción, no 46, 2011, pp. 65-68.

PÁEZ RÍOS, E., Repertorio de grabados españoles en la Biblioteca Nacional, Madrid, 19811985 , T. II, p. 344 , no 1591/68.

PÉREZ DE DOMINGO, L., El escultor Juan Pascual de Mena en Madrid, Fundación Universitaria Española, Madrid, 2007.

RAMÍREZ MARTÍNEZ, J. M., Torrecilla en Cameros: guía histórico-artística, Torrecilla en Cameros, 1993.

RAMÍREZ MARTÍNEZ, J. M., “Luis Salvador Carmona en Lumbreras de Cameros y Calahorra", Kalakorikos, no 2, 1997, pp. 97-113.

RAMÍREZ MARTÍNEZ, J. M., “Juan Pascual de Mena en San Millán de la Cogolla", Kalakorikos, no 2, 1997, pp. 301-308.

RAMÍREZ MARTÍNEZ, J. M., “Juan Pascual de Mena en Ortigosa de Carneros", Revista Siete Ríos, Logroño, no 6, 1997, p. 15.

RUIZ BARRERA, M. T., "Una obra documentada de Diego Martínez de Arce y Juan Pascual de Mena en el convento madrileño de las Góngoras", Estudios: revista trimestral publicada por los Frailes de la Orden de la Merced, no 237, 2008, pp. 103-112.

SÁNCHEZ RIVERA, J. Á., “El retablo mayor de la iglesia del convento de mercedarias de la Purísima Concepción en Madrid",
Cuadernos de Arte e Iconografía, no 25, 2004, pp. 197-214.

SÁNCHEZ RIVERA, J. Á.,, “El escultor Fernando del Cid. Algunos datos sobre su vida y su actividad artística", Archivo Español de Arte, no 331, 2010, pp. 249-266.

TABAR ANITUA, F., “En las Calatravas de Madrid: Un maestro, Villabrille, un discípulo, Salvador Carmona y un rival, Pascual de Mena", en Actas del IV coloquio nacional sobre la cultura en Andalucía. El escultor Luis Salvador Carmona (1708-1767). Conmemoración del III Centenario de su nacimiento (18 y 19 de septiembre de 2008), Serie Cuadernos de Estepa - Edición digital, no 2, 2013, pp. 167-178.

TRAVIESO, J. M., “Theatrum: San Antonio de Padua y San Francisco de Asís, obras de un escultor conocido por la Fuente de Neptuno de Madrid", 2015, consultado el 27 de julio de 2016. URL: http://domuspucelae.blogspot.com.es/2015/01/theatrum-san-antonio-y-san-francisco.html.

URREA, J., "La obra del escultor Luis Salvador Carmona en el País Vasco, Navarra y Castilla León", en Actas del IV coloquio nacional sobre la cultura en Andalucía. El escultor Luis Salvador Carmona (1708-1767). Conmemoración del III Centenario de su nacimiento (18 y 19 de septiembre de 2008), Serie Cuadernos de Estepa - Edición digital, no 2, 2013, pp. 57-70.

ZABALA MENÉNDEZ M., "Riojanos en el Real Cuerpo de la Nobleza de Madrid (1782-1909)", Boletín de la Asociación Riojana de Genealogía y Heráldica (A.R.G.H.), no 6, 2014, pp. 49-72. 